\title{
Consolidating a gender perspective in the PROCOSI network
}

Erica Palenque de la Quintana

Patricia Riveros Hamel

Population Council

Ricardo Vernon

Population Council

Follow this and additional works at: https://knowledgecommons.popcouncil.org/departments_sbsr-rh

Part of the Demography, Population, and Ecology Commons, Gender and Sexuality Commons, Health Services Research Commons, and the International Public Health Commons How does access to this work benefit you? Let us know!

\section{Recommended Citation}

de la Quintana, Erica Palenque, Patricia Riveros Hamel, and Ricardo Vernon. 2007. "Consolidating a gender perspective in the PROCOSI network," FRONTIERS Final Report. Washington, DC: Population Council. 


\title{
Consolidating a Gender Perspective in the PROCOSI Network
}

\author{
Erica Palenque de la Quintana \\ PROCOSI Project Coordinator \\ Ma. Patricia Riveros Hamel \\ Ricardo Vernon \\ FRONTIERS Program, Population Council
}

October 2007

This study is made possible by the generous support of the American people through the United States Agency for International Development (USAID) under the terms of Cooperative Agreement No. HRN-A-00-98-00012-00 and Population Council Subagreement AI05.19A. The contents are the responsibility of the FRONTIERS Program and do not necessarily reflect the views of USAID or the United States Government.
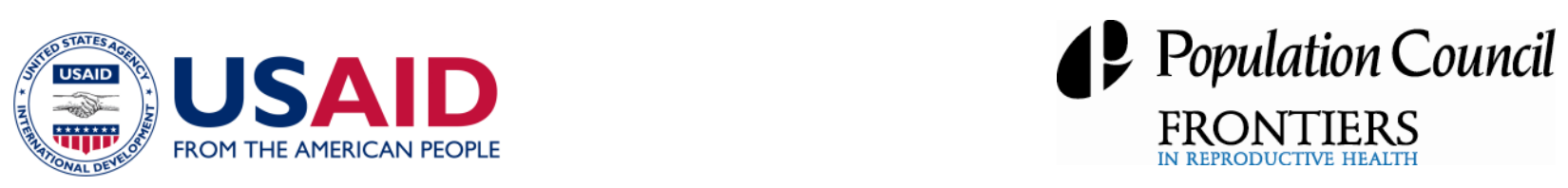


\section{SUMMARY}

The Integral Health Coordination Program (Programa de Coordinación en Salud Integral, or PROCOSI) is a network of 33 domestic and international non-government organizations (NGOs) in Bolivia. In 2000, PROCOSI developed a tool to explicitly incorporate a gender perspective in 17 of the NGOs participating in its Sexual and Reproductive Health Program by adapting the standards laid out in the "Manual for the Assessment of Quality of Care from a Gender Perspective" published by the International Planned Parenthood Federation/Western Hemisphere Region (IPPF/WHR). The NGOs developed action plans to address the areas of noncompliance with these standards, and a comparison of baseline and endline measures showed significant positive changes in several areas, including a decrease in unmet need for contraception, and modest changes in communication and decision-making between women and their partners. Despite these promising results, the average financial and opportunity costs of the intervention were very high (US\$23,148) and problems were found with the selection of standards and with institutionalization of improvement activities.

To solve these problems, a system was developed to certify the service delivery and management support NGOs as "Gender-Sensitive." The certification system is based on an initial selfassessment by teams consisting of staff from service delivery (clinical) or management support (administrative) NGOs, followed by the development and implementation of activities to improve the gaps found until a minimum of 80 percent of the designated quality and gender standards have been met. Each team or NGO implements all the necessary activities with their own resources and then conducts a second self-assessment. If this shows that the improvement goals have been met, the NGO requests an external evaluation to verify compliance with the standards. If the external evaluation shows compliance, the NGO is certified as 'gendersensitive' at a public event. This certification is only valid for two years, which means the NGO has to repeat the procedure periodically.

At the beginning of the project, none of the service delivery or management support NGOs met all the standards. At the project's end, 14 of the 15 participating NGOs had reached compliance with at least 80 percent of the proposed standards (65 standards for service delivery NGOs or 17 standards for management support NGOs), and their achievement was recognized in a public certification ceremony. Among the service delivery NGOs, the standards that were still not completely met were those related to institutional policies and practices and to some provider practices. NGOs were able to identify unmet quality standards and carry out actions to achieve compliance without external financing and with minimal technical assistance. The average cost of carrying out activities to incorporate a gender perspective in the service delivery NGOs was $\$ 4,184$ compared with $\$ 2,528$ per management support NGO. In both types of NGO, the highest proportion of cost was the personnel time, and this was much higher for management support NGOs (92\%) than for service delivery NGOs (49\%). Thus the project succeeded in developing a more cost-effective strategy to incorporate a gender perspective.

To date, the strategy has been disseminated at a National Certification Ceremony, attended by directors of organizations affiliated with the PROCOSI network and representatives of other public and private health organizations; at a workshop, attended by representatives from international organizations and the Ministry of Health; and at a methodology workshop for PROCOSI network health NGOs interested in replicating the strategy. 


\section{TABLE OF CONTENTS}

Summary

I. Background …......................................................................................................................... 1

II. Objectives ........................................................................................................................ 3

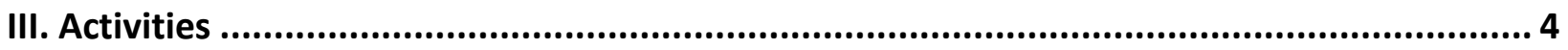

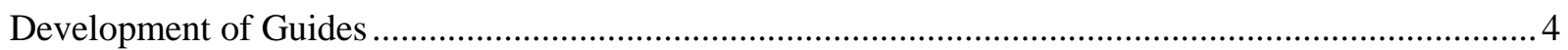

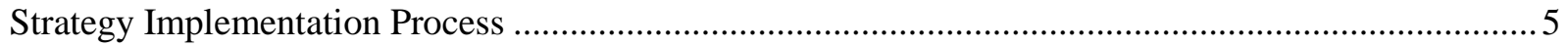

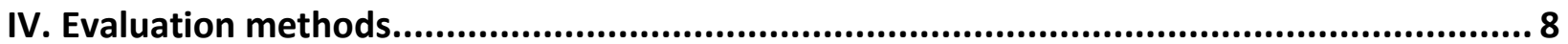

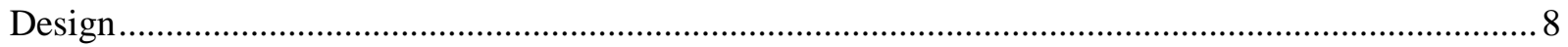

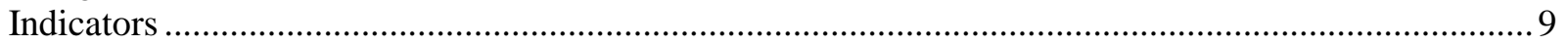

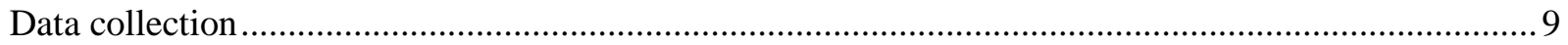

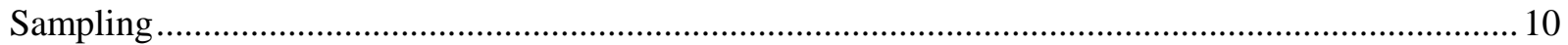

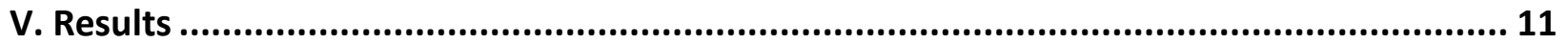

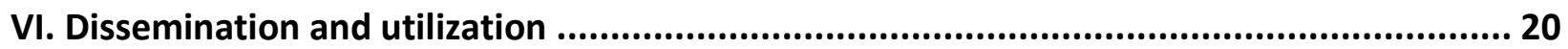

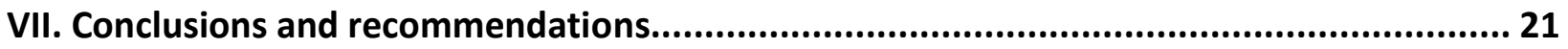

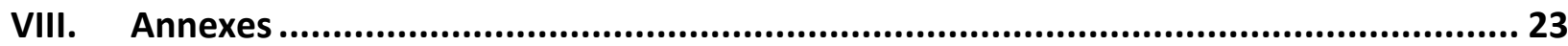

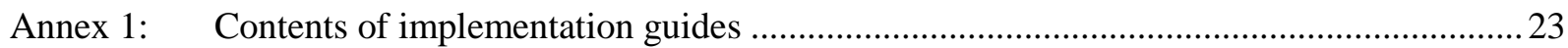

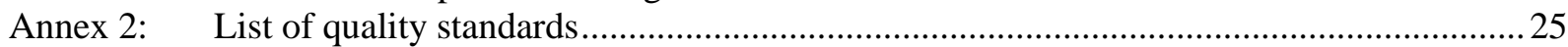

Annex 3: Unmet standards and actions suggested to improve them ...............................................2

Annex 4: Changes in unmet standards, pre- and post-intervention ................................................4

Annex 5: Costs by unit and type of expenditure (in \$US) ..............................................................4

Annex 6: Costs per unit and other distribution of type of expenses .................................................. 43 


\section{BACKGROUND}

The Integral Health Coordination Program (PROCOSI) is a network of 33 domestic and international non-government organizations (NGOs) in Bolivia. It coordinates and implements programs to improve the population's health, including a Sexual and Reproductive Health Program that provides services to nearly 100,000 women of reproductive age in the poorest and most marginalized areas in the country. These women frequently fail to go to public sector health services or participate in community health events. For this reason, PROCOSI's premise is that empowerment and capacity building must be a fundamental component of women's health care, as well as training that seeks to improve the life conditions of communities in general and women in particular. Through greater knowledge, improved social attitudes, and a wider social network, women learn to recognize their health care needs and to perceive their own participation as an expression of the full exercise of their rights.

One of the main barriers to women's increased use of health services and participation in health activities is a longstanding history of discrimination. Change must be founded upon an intercultural and gender perspective that seeks to overcome inequalities between men and women and between Spanish-speaking and indigenous populations. These inequalities exist not only in the social and cultural environment, but also in health service delivery. Therefore, health service providers need to institutionalize and put into action gender- and culture-sensitive perspectives through an appropriate institutional framework and training.

In 2000, PROCOSI implemented a project to explicitly incorporate a gender perspective in 17 NGOs that participated in its Sexual and Reproductive Health Program. As a first step in operationalizing the concept of a gender perspective, PROCOSI adapted the "Manual for evaluating quality of care from a gender perspective" by the International Planned Parenthood Federation/Western Hemisphere Region (IPPF/WHR) ${ }^{1}$. This manual recommends first conducting a baseline assessment to assess the situation according to several standards and indicators, subsequently preparing work plans to improve substandard indicators or unmet standards of quality, and finally conducting an endline assessment to determine the degree to which conditions changed. To carry out baseline and endline assessments, five instruments were used (observation guides and questionnaires for users and service providers) that compile information on 71 gender and quality of care indicators. These include indicators on institutional policies and practices, provider practices, client comfort and satisfaction, use of gendered language, information, education and communication (IEC) with clients and providers, and monitoring and evaluation of activities and programs.

Each participating NGO formed a team from among its own employees to carry out the baseline and endline assessments. These teams presented the baseline results to staff in their organizations during a workshop and participants identified several indicators that needed improvement. These indicators were used to formulate a plan in which actions to improve each selected indicator were set out in detail: the date when each action should be completed, the person responsible for carrying out each action, and the resources needed to implement them.

\footnotetext{
${ }^{1}$ International Planned Parenthood Federation/Western Hemisphere Region. 2000. Manual to Evaluate Quality of Care from a Gender Perspective. New York: IPPF/WHR.
} 
PROCOSI provided each institution with $\$ 3,500$ to implement the actions proposed in the plans and to provide training on 13 subjects covering implementation of the strategy as well as thematic and conceptual contents that all employees in participating organizations should know. PROCOSI also created a package of eight types of printed materials to explain concepts to clients and providers, and provided a package of five related videos to each participating health center/NGO for use in waiting rooms.

On average, each organization proposed carrying out 15 improvement actions and managed to finish two-thirds of them before the end of the project. Interventions included changing infrastructure to make services more comfortable for clients (such as having rooms for tending to babies and areas for children); enhancing medical equipment; improving treatment and counseling of clients; and modifying institutional policies.

Comparison between baseline and the endline measures showed significant changes in several areas. For example, most organizations established explicit institutional policies to forbid gender-based discrimination; privacy during service delivery became almost universal; and the systematic screening of needs and client satisfaction with services increased considerably. Even more importantly, the proportion of clients who left the clinics without the contraceptive method they would have liked to use decreased by nearly 35\%. A follow-up study of female clients and their partners carried out three months after their visit to the health centers showed that modest changes had also occurred in communication between women and their partners and in joint decision-making, strengthening women's capacity to give their points of view on subjects related to sexual and reproductive health and to make decisions about their personal lives and health care $^{2}$.

Despite these promising results, the following problems were observed:

1) Each organization selected only those indicators or standards of quality that they wished to improve. Although the approach proved effective in beginning a quality improvement process, it did not guarantee that clients of participating organizations would receive a quality of service consistent with the set of standards used as a reference. For example, the final quality of service of an organization that did not meet 35 standards and which then selected five of these standards for improvement would be very different from the quality of service for an organization that did not comply with 10 out of 71 indicators and managed to improve five of these 10 indicators. From PROCOSI's point of view (and their clients), it would be much better if the service delivery NGOs in their network provided services with a consistent quality of care and that was known by their clients.

2) The process of quality improvement had a beginning and an end, and therefore this approach did not lead to the institutionalization of improvement processes.

3) Each organization spent an average of US\$23,148 in implementing quality improvement activities, of which nearly 50 percent was on personnel time and the rest comprised direct costs, such as training and IEC materials provided by PROCOSI. Few organizations could replicate this approach at such a cost and a strategy must be found that achieves the same results at a much lower cost.

\footnotetext{
${ }^{2}$ Palenque, Erica et al. 2004. Effects and cost of implementing a gender-sensitive reproductive health program, FRONTIERS Final Report. Washington DC: Population Council.
} 
To address these problems, PROCOSI and FRONTIERS initiated a two-year project in 2005 to develop a system to certify service delivery NGOs and their management support NGOs as "Gender-Sensitive." The certification system entails an initial self-assessment followed by the development and implementation of improvement plans, until a minimum of 80 percent of a set of quality and gender standards have been met. Teams from the NGOs implement all training activities, infrastructure changes, procedures, and revisions of statutes with their own resources. Once an internal assessment by the team shows that this goal has been met, the NGO requests an external evaluation to verify that the standards have been met, in which case the NGO receives certification at a public event. The certification is only valid for two years, however, so the NGO has to repeat the procedure periodically.

This strategy responds to the deficiencies of the approach tested in 2000, as the process guarantees a minimum compliance with reference standards of quality and hence a consistent quality of service in all participating NGOs. The certification is made public with a plaque placed at the clinic, which informs clients of the quality offered by the unit. It also improves cost-effectiveness, since teams carry out all the planned activities with their own resources, and so costs are, for the most part, the opportunity costs of the health workers' time dedicated to providing better services. Detailed information on how this certification process was implemented is provided below.

\section{OBJECTIVES}

\section{General objective:}

To develop and test a cost-effective strategy to certify health service and management support NGOs in the PROCOSI network as providers of quality services with a gender perspective.

\section{Specific objectives:}

1. Develop guides for implementing the strategy, including a general guide for implementation procedures, a self-assessment guide for quality from a gender perspective, a self-learning guide on the necessary concepts to meet standards of quality, and a guide to measure strategy costs.

2. Determine the interest of organizations in participating in a self-certification process.

3. Evaluate the degree to which organizations can self-evaluate their compliance with standards of quality from a gender perspective and propose and implement actions for reaching standards that have not been met.

4. Evaluate whether the implementation of solutions has an effect on compliance with standards of quality.

5. Measure the costs of implementing the strategy.

6. Certify organizations that have complied with a minimum of $80 \%$ of the proposed standards as Gender Sensitive Quality Service Providers. 


\section{ACTIVITIES}

\section{Development of Guides}

The first activity was to design the strategy and develop support materials to guide service delivery and management support NGOs through the certification process. Four Spanishlanguage guides were developed as follows (their contents are listed in Annex 1):

i. $\quad$ Procedures Guide: The "Procedures Guide for Health Institutions and Establishments Seeking to Obtain Certification as Gender-Sensitive Quality Health Center/NGO" describes the process that organizations must follow to implement the certification strategy. This guide is aimed at directors and coordinators of NGOs. Various experiences with certification systems in Bolivia were reviewed, such as the Observatory of Quality (Observatorio de la Calidad), an initiative by the Ministry of Health (MOH) with the support of the World Bank, and the "Baby Friendly Hospital" strategy supported by UNICEF. In both cases, PROCOSI and FRONTIERS staff interviewed the managers of these initiatives and visited health centers and hospitals that had participated in them, such as the Los Andes Hospital in El Alto, San Gabriel Hospital in La Paz, and the Cotalma NGO that certifies women- and childfriendly hospitals.

ii. Self-Training Guide: Many of the standards of quality selected require that personnel know specific concepts, such as the meaning of gender and reproductive health services. To facilitate learning this information, a self-training guide was developed that staff members can study on their own. The guide presents an explanation of the concept underlying each standard and the actions recommended for the standard to be met. For its development, PROCOSI's gender-sensitivity materials were reviewed, as well as materials on gender from projects in other national and international health organizations. Along with the guide, several materials were provided to support the activities, including a copy of the BRISTOL almanac, which contains dates from the Catholic calendar of saint's days and the moon calendar, which are used to calculate time in Andean communities (to facilitate follow-up), as well as a leaflet, a poster on user rights, and a video on couple relationships and quality of care services produced by PROCOSI.

iii. Assessment Guide: This guide is aimed at staff members involved in the assessment of compliance with quality standards in each NGO. It provides step-by-step instructions for conducting the assessment, presents the standards that need to be met and the instruments used to measure their compliance, and outlines procedures for processing information.

iv. Guide for Measuring Implementation Costs: This guide shows how to measure the direct and indirect costs incurred in implementing the strategy through five instruments that measure:

- Costs of changes in institutional policies and practices

- Costs of meetings/workshops

- Costs of improvements in infrastructure, equipment, or furniture

- Costs of development and distribution of IEC and training material

- Supervision costs. 
This guide also includes an information system that allows costs to be automatically calculated by means of electronic forms.

\section{Strategy Implementation Process}

\section{i. Invitation to NGOs to participate}

Twenty-seven NGOs with health service delivery units affiliated to the PROCOSI network were invited to participate in this project. Out of 27 NGOs, 25 said they were interested in participating to certify either their service delivery units, management support units, or both. During the project, 10 NGOs discontinued participating. Three NGOs that provide support to $\mathrm{MOH}$ health facilities decided that they did not have the necessary control and support to carry out project activities; four NGOs reported a lack of human and financial resources to implement activities; one NGO preferred to postpone its participation because it did not have a defined sexual and reproductive health program; and two NGOs could not continue implementing the proposed activities as they were undergoing program and personnel restructuring. Table 1 lists the NGOs that were invited to participate and the type of participation they chose or the reasons for not continuing in the project.

\section{ii. NGO training workshop on the strategy}

A two-day workshop was held, involving about three staff members from each NGO, to explain the methodology, instruments, and materials necessary to carry out project activities. The morning of the first day was dedicated to talks related to the subjects of gender, quality and health given by representatives from national and international organizations such as the Ministries of Health and of Women's Affairs, USAID, UNFPA, and PAHO/WHO. In the afternoon, the 65 assessment indicators were presented and explained, as well as the assessment forms, action plans and the use of procedure and self-training guides. Participants did practical exercises for using the observation guides and client and provider questionnaires, simulating data collection at a health center. Several preliminary versions of the action plans for each participating unit were also developed.

\section{iii. Self-diagnosis by NGOs}

Upon returning to their institutions, coordinators held a meeting with all NGO personnel. The list of standards was analyzed in the meeting and those in charge of each area were asked which ones the NGO currently complied with and which it did not. In this way, based on the knowledge and perceptions of the NGO staff, the standards to be improved were selected (in subsequent supervisory visits, however, it was discovered that most NGOs had not used the instruments provided to them).

\section{iv. Development of Action Plans}

Next, teams put together an action plan to improve the standards that had not already been fulfilled and that they had selected for improvement. According to the guidance given, the plan should detail the activities that would need to be undertaken to correct the unmet standards, who in the organization would be in charge of each activity, a timetable for implementation, and the resources necessary to carry out actions. 
Table 1: NGO participation in the certification process

\begin{tabular}{|c|c|c|c|}
\hline Name & $\begin{array}{l}\text { Accepted to } \\
\text { participate? }\end{array}$ & $\begin{array}{c}\text { Units by certification } \\
\text { type }\end{array}$ & Reason for discontinuation \\
\hline APROSAR & Yes & 1. Health Unit & \\
\hline APSAR & Yes & 2. Health Unit & \\
\hline Ayuda en Acción & Yes & 3. Health Unit & Dependent on $\mathrm{MOH}$ \\
\hline CARE & Yes & $\begin{array}{l}\text { 4. Parent organization } \\
\text { 5. Health Unit } \\
\text { 6. Health Unit }\end{array}$ & $\begin{array}{l}\text { Dependent on } \mathrm{MOH} \\
\text { Dependent on } \mathrm{MOH}\end{array}$ \\
\hline CRS & No & & \\
\hline CEMSE & Yes & 7. Health Unit & \\
\hline CEPAC & Yes & 8. Parent organization & \\
\hline Cáritas Boliviana & Yes & $\begin{array}{l}\text { 9. Health Unit } \\
\text { 10. Health Unit }\end{array}$ & $\begin{array}{l}\text { Lack of Resources } \\
\text { Lack of Resources }\end{array}$ \\
\hline CIES & Yes & 11. Health Unit & \\
\hline COMBASE & Yes & 12. Health Unit & Lack of Resources \\
\hline CSRA & Yes & 13. Health Unit & \\
\hline CRECER & Yes & 14. Parent organization & \\
\hline CCF & No & & \\
\hline Esperanza Bolivia & Yes & 15. Parent organization & \\
\hline FHI Bolivia & Yes & 16. Parent organization & \\
\hline $\begin{array}{l}\text { Fundación San } \\
\text { Gabriel }\end{array}$ & No & & \\
\hline IPTK & Yes & 17. Health Unit & \\
\hline $\begin{array}{l}\text { Plan International } \\
\text { Bolivia }\end{array}$ & No & & \\
\hline Promujer & Yes & $\begin{array}{l}\text { 18. Health Unit } \\
\text { 19. Parent organization }\end{array}$ & \\
\hline $\begin{array}{l}\text { Project Concern } \\
\text { International }\end{array}$ & Yes & 20. Parent organization & \\
\hline Prosalud & No & & \\
\hline SACOA & Yes & 21. Health Unit & Organizational Changes \\
\hline $\begin{array}{l}\text { Save the Children } \\
\text { Canada }\end{array}$ & No & & \\
\hline $\begin{array}{l}\text { Save the Children } \\
\text { USA }\end{array}$ & No & & \\
\hline Servir & Yes & 22. Health Unit & Organizational Changes \\
\hline Sexsalud & Yes & $\begin{array}{l}\text { 23. Health Unit } \\
\text { 24. Health Unit }\end{array}$ & Lack of Resources \\
\hline Visión Mundial & Yes & 25. Health Unit & Undefined $\mathrm{RH}$ program \\
\hline
\end{tabular}




\section{v. First follow-up visit and development of a diagnosis}

Based on these action plans, PROCOSI's Project Coordinator developed a follow-up and training supervision plan. This plan consisted of frequent contact via email, telephone conference calls, and two field visits per unit to reinforce knowledge acquired during the workshop, review the progress of proposed improvements, collect information on costs, and train personnel in putting internal assessments into practice. After the first series of follow-up visits, it was evident that most organizations had not used the instruments provided to make their diagnoses and that their assessments were based on perceptions. Therefore, the PROCOSI Project Coordinator and the local coordinators did an internal assessment using all project instruments during the first supervision visit.

\section{vi. Reformulation of action plans and implementation of solutions}

From the results of this instrument-based assessment, organizations then reformulated their action plans and designed new activities to reach the desired standards of quality.

\section{vii. Follow-up of action plans}

During the following months, PROCOSI's Project Coordinator visited the participating units twice to follow up on their progress and to clarify questions on the methodology, suggest activities to improve indicators, collect data, and gather information on costs. Further follow-up of activities was made via email. Although some organizations reported periodically on their progress, as agreed during the first workshop, most waited until the supervision visits to do so.

\section{viii. Training of inter-institutional evaluators}

To carry out the external validation evaluations, a two-day training workshop was held with nine participants, among them the most committed coordinators from the organizations that participated in this project and PROCOSI's managers. The agenda included reviewing and practicing the use of data collection guides and questionnaires, the manual and automatic dataentry systems, and the review of check lists. Also, a copy of the Assessment Guide was given to the participants and reviewed.

\section{ix. Final external evaluations}

The PROCOSI Project Coordinator made two follow-up visits using the assessment instruments, and participating NGOs carried out their own internal assessments to verify that standards had been met and to request the subsequent external evaluation. Teams from 14 of the 15 NGOs made their internal assessment to verify compliance with standards of quality and requested that a first external evaluation be done by personnel from PROCOSI central offices and personnel from other NGOs affiliated to the network. The first external evaluations were carried out over a period of two months, and only one organization did not meet the minimum required standards.

After this assessment was finished, an inter-institutional assessment committee was to have been established to carry out the final certification of compliance with the standards. This committee was to include representatives from domestic and international organizations (EngenderHealth, USAID, UNFPA and OPS, Ministry of Health, SEDES, the Vice-Ministry of Gender, Coordination for Women's Affairs, and others) who were informed of the project's progress 
throughout. However, many representatives stated that they lacked the time and resources to take part in the final assessment. Thus it was agreed that the PROCOSI Project Coordinator and the FRONTIERS Project Monitor would conduct the final external evaluation.

\section{x. Certification of Participating Units}

Formal recognition of compliance with a minimum score of $80 \%$ on the gender and quality standards was given in a National Certification Ceremony with the participation of representatives from NGOs affiliated to the PROCOSI network, international organizations, the Ministry of Health and local press. During the ceremony, representatives from each certified NGO were given a plaque of merit, an accreditation certificate, the final external evaluation report, and a CD-ROM with photographs of project activities. Certificates of participation were also given to members of the assessment committee. The national daily press published an account of the ceremony and of the organizations' achievements on the Sunday following the event, the day with the highest circulation.

After the National Certification Ceremony, certified NGOs had the option of organizing local ceremonies for uncovering the plaque of merit. To date, three NGOs have carried out ceremonies in the presence of government representatives and health authorities, two NGOs expressed no interest in doing so, and the remainder has set dates in the following two months.

\section{EVALUATION METHODS}

\section{Design}

A non-experimental pretest/post-test design was used to evaluate the effectiveness of the intervention. Due to problems in implementation of their baseline assessments, NGO teams received technical assistance from PROCOSI's Project Coordinator to conduct a second baseline assessment. The coordinator and the teams conducted an endline assessment that was then confirmed through a validation assessment by an external team of evaluators. This design can be represented as follows:

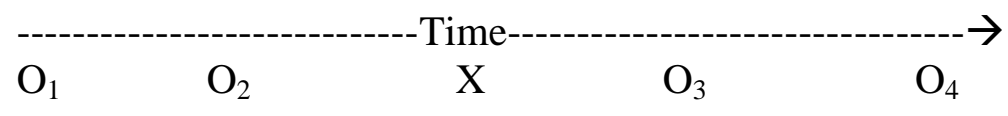

Where:

O1 Represents the initial self-assessment by the work teams in the health center/NGO

$\mathbf{O}_{2}$ Represents the baseline assessment conducted by the work teams with TA from the PROCOSI coordinator

X Represents the implementation of activities to meet standards of quality and gender

$\mathbf{O}_{3}$ Represents the endline self-assessment made by work teams with the TA by PROCOSI's project coordinator

$\mathbf{O}_{4} \quad$ Represents the independent assessment made by external certification teams

The unit of analysis for the evaluation was each health facility or the management support unit of the participating NGO, and is termed the certification unit. Two types of certification units participated and were evaluated using different indicators. 


\section{Indicators}

The service delivery units were evaluated using 65 indicators of quality and gender sensitivity standards, most of them related to service delivery. Indicators measured eight standards:

- Institutional policies and practices (14 indicators)

- Provider practices (28 indicators)

- Personnel knowledge (3 indicators)

- Client comfort (2 indicators)

- Client satisfaction (11 indicators)

- Use of gendered language (2 indicators)

- Information, education, communication and training (4 indicators)

- Monitoring and evaluation (1 indicator).

The management support units include the management and administrative components in the NGO headquarters (e.g. personnel, accounting, administration, supervision), and these were evaluated using 17 indicators measuring five standards:

- Institutional policies and practices (10 indicators)

- Personnel knowledge (2 indicators)

- Personnel satisfaction (1 indicator)

- Use of gendered language (2 indicators)

- Information, education, communication, and training (2 indicators).

These 17 indicators have no relation with the direct delivery of services and focus on such organizational characteristics as organization statutes, personnel participation, and office conditions.

These indicators were adapted from those used during the original project, which in turn were based on the 71 indicators originally proposed in the "Manual to Evaluate Quality of Care from a Gender Perspective" by IPPF/WHR. Indicators were adapted taking into account the experiences of health centers that participated in that program, the duplication of information found in two indicators, and the low applicability of five indicators. Five indicators were also rewritten to facilitate information-gathering and make their meaning clearer and six indicators to measure the facilities' capacity to care appropriately for indigenous clients were added ${ }^{3}$. Annex 2 lists the indicators.

\section{Data collection}

Three instruments were used to measure the 17 quality and gender standards in the management support units: a guide for reviewing institutional documents; a guide for observing general conditions; and a guide for interviewing personnel. Five instruments were used to measure the 65 quality and gender standards in service delivery units (and were pretested at the CIES clinic in El

\footnotetext{
${ }^{3}$ These indicators were developed based on the findings from another operations research project on the providing services for indigenous clients: Gonzales, Fernando; M.A. Martín, R. Pérez, and R. Vernon. 2005. Cross-cultural adaptation of reproductive health services in Bolivia, FRONTIERS Final Report. Washington, DC: Population Council.
} 
Alto): a guide for reviewing institutional documents; a guide for observing general aspects; a guide for observing provider-client interactions during counseling or consultations; a questionnaire for exit interviews with clients; and a questionnaire for interviews with personnel.

\section{Sampling}

Table 2 summarizes the number of interviews and observations for each instrument. The sample numbers are standardized for all phases of the certification process, except for the external assessment, for which the sample varies according to the daily mean number of clients. It ranged between two interviews, when there was an average of two clients per day, to 15 interviews when client loads averaged 36 clients per day. The following formula was used that allows for a representative sample with $90 \%$ confidence, expecting $90 \%$ prevalence of desirable cases, with an allowed error of $10 \%{ }^{4}$ :

Size of the sample $=$ 24.35

$1+(24.35$ / daily average of consultations $)$

Table 2: $\quad$ Sample sizes for each instrument, by type of assessment

\begin{tabular}{|l|l|l|}
\hline \multirow{2}{*}{\multicolumn{1}{|c|}{ Instrument }} & \multicolumn{2}{c|}{ Type of assessment } \\
\cline { 2 - 3 } & \multicolumn{1}{c|}{ Internal } & \multicolumn{1}{c|}{ External } \\
\hline Guide for reviewing documents & All documents & All documents \\
\hline Guide for observing general conditions & All facilities & All facilities \\
\hline $\begin{array}{l}\text { Guides for observing provider-client interactions during } \\
\text { counseling and consultations. }\end{array}$ & $\begin{array}{l}2 \text { consultations and } 2 \\
\text { counseling sessions }\end{array}$ & $\begin{array}{l}4 \text { consultations and } 2 \\
\text { counseling sessions }\end{array}$ \\
\hline Client interview questionnaires & $\begin{array}{l}4 \text { consultation clients } \\
\text { and 4 counseling } \\
\text { clients }\end{array}$ & $\begin{array}{l}\text { According to the } \\
\text { formula and average } \\
\text { number of clients }\end{array}$ \\
\hline Personnel interview questionnaires & 2 providers & 7 providers \\
\hline
\end{tabular}

Generally, when the desired standard is found in $80 \%$ of all the cases (according to interviews or observations) for one indicator, the standard is considered to be met. The assessment guide describes in detail how information must be processed from the instruments to determine whether the standard has been met or not. To facilitate these calculations, a management information system was developed (based on spreadsheets to which data from the instruments is transferred) as well as one with electronic spreadsheets for those with computer data processing capabilities.

$4 \quad$ Kish, L. 1965. Survey Sampling. New York: John Wiley \& Sons. 


\section{RESULTS}

In the following section we present the results in terms of answers to four questions that show if the project objectives were met:

1. Can the organizations identify problems related to compliance with standards of quality and propose solutions that do not rely on external funding, with minimal technical assistance?

Table 3 shows the number of standards that were not met by NGOs during the first internal assessment, and the number of actions proposed to meet those standards. Among service delivery units, the NGOs had an average of 56 unmet standards and each NGO proposed to carry out an average of 72 actions to rectify these weaknesses. In the case of the management support units, almost no standard had been met at the beginning of the project, and each management unit proposed an average of 22 actions to improve their status.

Table 3: Number of unmet standards in the first assessment and number of actions proposed by NGO

\begin{tabular}{|c|c|c|}
\hline Participating Unit & $\begin{array}{l}\text { Number of unmet } \\
\text { standards at first } \\
\text { assessment }\end{array}$ & $\begin{array}{l}\text { Number of actions } \\
\text { proposed to solve } \\
\text { noncompliance }\end{array}$ \\
\hline Service delivery units & (65 standards) & \\
\hline Unit1 & 39 & 11 \\
\hline Unit 2 & 52 & 60 \\
\hline Unit 3 & 60 & 123 \\
\hline Unit 4 & 62 & 117 \\
\hline Unit 5 & 51 & 99 \\
\hline Unit 6 & 65 & 34 \\
\hline Unit 7 & 65 & 122 \\
\hline Unit 8 & 56 & 10 \\
\hline Averages for service delivery units & 56 & 72 \\
\hline Management support unit & (17 standards) & \\
\hline Unit 1 & 17 & 26 \\
\hline Unit 2 & 16 & 20 \\
\hline Unit 3 & 17 & 41 \\
\hline Unit 4 & 17 & 8 \\
\hline Unit 5 & 17 & 41 \\
\hline Unit 6 & 16 & 8 \\
\hline Unit 7 & 17 & 14 \\
\hline Average for management support units & 17 & 22 \\
\hline
\end{tabular}


At the beginning of the project, all service delivery units were in noncompliance with 31 of the 65 service-related standards, and all management support units were in noncompliance with 16 out of 17 standards. Table 4 shows the number of actions proposed by the units to fulfill some of the unmet standards of quality, an example of the most commonly proposed solution by units, and the number of units that suggested this solution. Annex 3 presents the complete table of all solutions proposed by the units for each unmet standard.

Table 4: $\quad$ Examples of unmet standards and actions suggested to improve them

\begin{tabular}{|l|c|l|c|}
\hline \multicolumn{1}{|c|}{ Examples of unmet standards } & $\begin{array}{c}\text { Number of } \\
\text { actions to } \\
\text { improve } \\
\text { standard }\end{array}$ & Example of proposed solution & $\begin{array}{c}\text { Number } \\
\text { of units } \\
\text { proposing } \\
\text { this } \\
\text { solution }\end{array}$ \\
\hline $\begin{array}{l}\text { I.2 There is a declaration in place } \\
\text { that forbids gender-based } \\
\text { discrimination }\end{array}$ & 5 & $\begin{array}{l}\text { Writing an institutional declaration that } \\
\text { forbids women's discrimination. }\end{array}$ & 7 \\
\hline $\begin{array}{l}\text { I.4 There is a declaration that } \\
\text { forbids abuse of power in the } \\
\text { institution }\end{array}$ & 3 & $\begin{array}{l}\text { Writing an institutional declaration that } \\
\text { forbids the abuse of power in the } \\
\text { institution. }\end{array}$ & 7 \\
\hline $\begin{array}{l}\text { I.11 At least 50\% of sexual and } \\
\text { reproductive health consultations } \\
\text { are offered to couples }\end{array}$ & 8 & Promotion of consultations for couples & 8 \\
\hline $\begin{array}{l}\text { II.25 At least 80\% of personnel } \\
\text { keep doors and windows closed to } \\
\text { avoid air currents during the } \\
\text { consultation }\end{array}$ & 2 & $\begin{array}{l}\text { Improve outpatient and counseling } \\
\text { consultation environments, ensuring } \\
\text { they have all that is necessary to } \\
\text { maintain privacy during their visit. }\end{array}$ & 8 \\
\hline $\begin{array}{l}\text { III.1 At least } 80 \% \text { of personnel } \\
\text { recognize the definition of sexual } \\
\text { and reproductive health }\end{array}$ & 8 & $\begin{array}{l}\text { Training workshop on topics of health } \\
\text { and gender }\end{array}$ & 7 \\
\hline $\begin{array}{l}\text { III.3 At least } 80 \% \text { of personnel } \\
\text { know the definition of gender }\end{array}$ & 6 & Sensitizing and training in gender & 7 \\
\hline $\begin{array}{l}\text { V.2 Conditions of cleanliness and } \\
\text { comfort are satisfactory }\end{array}$ & 8 & Monitoring and supervision & 7 \\
\hline $\begin{array}{l}\text { V.3 Equipment is available and in } \\
\text { good condition }\end{array}$ & 4 & $\begin{array}{l}\text { Maintenance and reposition of medical } \\
\text { equipment and instruments }\end{array}$ & 3 \\
\hline $\begin{array}{l}\text { VI.1 Non-discriminatory language is } \\
\text { used }\end{array}$ & 6 & Sensitizing of personnel & 7 \\
\hline $\begin{array}{l}\text { VII.3 There is visual and accessible } \\
\text { information on the health } \\
\text { establishment (services delivered, } \\
\text { schedules and list of prices) }\end{array}$ & $\begin{array}{l}\text { Development of list of presentations, } \\
\text { costs, services delivered and visiting } \\
\text { hours }\end{array}$ & 7 \\
\hline
\end{tabular}

Noncompliance with gender and quality standards was quite widespread. Table 5 below shows that at the beginning of the project, no participating unit - either in service delivery or management - complied with all the indicators in any of the subgroups of standards. In summary, Tables 3, 4 and 5 reflect low compliance with the proposed gender and quality standards at the beginning of the project, both in health centers and administrative offices. 
We can conclude, therefore, that organizations can identify the standards they do not meet and can propose activities to comply with them. It must be noted, however, that at the beginning of the intervention, several organizations did a self-diagnosis based on their perceptions and experiences, and the results of this exercise were very lenient, since they indicated high compliance with standards. Thus it is vital to ensure the use of standardized instruments and methods that permit a neutral view of conditions, as the perceptions and experiences of health team members alone tend to be insufficiently objective.

Table 5: $\quad$ Actions proposed by units to improve standards, by group of standards

\begin{tabular}{|c|c|c|c|c|}
\hline Group of standards & $\begin{array}{l}\text { Number of } \\
\text { standards }\end{array}$ & $\begin{array}{l}\text { Number of } \\
\text { units that do } \\
\text { not meet at } \\
\text { least one } \\
\text { standard }\end{array}$ & $\begin{array}{l}\text { Number of } \\
\text { unmet } \\
\text { standards } \\
\text { by all units }\end{array}$ & $\begin{array}{l}\text { Number of } \\
\text { actions } \\
\text { proposed to } \\
\text { improve } \\
\text { standards }\end{array}$ \\
\hline \multicolumn{5}{|l|}{ Service delivery units } \\
\hline Institutional policies and practices & 14 & 8 & 87 & 118 \\
\hline Provider practices & 28 & 8 & 193 & 126 \\
\hline Provider knowledge & 3 & 8 & 22 & 124 \\
\hline Client comfort & 2 & 8 & 13 & 5 \\
\hline Client satisfaction & 11 & 8 & 84 & 94 \\
\hline Use of gendered language & 2 & 8 & 16 & 4 \\
\hline $\begin{array}{l}\text { Information, education, communication } \\
\text { and training }\end{array}$ & 4 & 8 & 31 & 101 \\
\hline Monitoring and assessment & 1 & 8 & 8 & 4 \\
\hline Total service delivery units & 65 & 64 & 454 & 576 \\
\hline \multicolumn{5}{|l|}{ Management support units } \\
\hline Institutional policies and practices & 10 & 7 & 68 & 68 \\
\hline Personnel knowledge & 2 & 7 & 14 & 37 \\
\hline Personnel satisfaction & 1 & 7 & 7 & 10 \\
\hline Use of gendered language & 2 & 7 & 14 & 12 \\
\hline $\begin{array}{l}\text { Information, education, communication } \\
\text { and training }\end{array}$ & 2 & 7 & 14 & 31 \\
\hline Total management support units & 17 & 35 & 117 & 158 \\
\hline
\end{tabular}

\section{Do organizations implement proposed actions to solve problems?}

Table 6 shows that by the time of the follow-up evaluation visits, most actions proposed by participating units to improve standards had been implemented. One of the service delivery units did not implement any of the proposed actions due to lack of support by its administrative office. 
In the case of management support units, the staff of one unit proposed sensitization workshops, but these were not held due to personnel turnover and this unit did not manage to incorporate new policies within its statutes. Another unit was unable to implement some of the proposed workshops due to lack of time. Annex 4 compares the initial and final scores for the most frequently unmet standards.

Table 6: $\quad$ Compliance with actions proposed by the units

\begin{tabular}{|c|c|c|c|}
\hline \multirow[t]{2}{*}{ Units } & \multirow{2}{*}{$\begin{array}{l}\text { Total actions } \\
\text { proposed }\end{array}$} & \multicolumn{2}{|c|}{ Were actions implemented? } \\
\hline & & YES & NO \\
\hline \multicolumn{4}{|l|}{ Service delivery units } \\
\hline Unit 1 & 11 & 11 & 0 \\
\hline Unit 2 & 60 & 60 & 0 \\
\hline Unit 3 & 123 & 120 & 0 \\
\hline Unit 4 & 117 & 116 & 0 \\
\hline Unit 5 & 99 & 99 & 0 \\
\hline Unit 6 & 34 & 34 & 0 \\
\hline Unit 7 & 122 & 122 & 0 \\
\hline Unit 8 & 10 & 0 & 10 \\
\hline Total service delivery units & 576 & 566 & 10 \\
\hline Averages service delivery units & 72 & 71 & 1 \\
\hline \multicolumn{4}{|l|}{ Management support units } \\
\hline Unit 1 & 26 & 20 & 6 \\
\hline Unit 2 & 20 & 20 & 0 \\
\hline Unit 3 & 41 & 39 & 2 \\
\hline Unit 4 & 8 & 8 & 0 \\
\hline Unit 5 & 41 & 41 & 0 \\
\hline Unit 6 & 8 & 8 & 0 \\
\hline Unit 7 & 14 & 14 & 0 \\
\hline Total management support units & 158 & 150 & 8 \\
\hline Average management support units & 22 & 21 & 1 \\
\hline
\end{tabular}

The units used several approaches to implement improvements outlined in their action plans, for example:

- The highest authorities (program directors and managers) were involved in all the units to obtain support for actions implemented.

- One unit is currently working to increase coworker satisfaction by means of "Social Responsibility." A survey was implemented for personnel to identify their needs and requirements. Based on the findings, the unit is now offering health service personnel lower prices for services at the organization's health centers. This unit is also seeking to 
offer more flexibility to grant short absences to solve family situations and to provide daycare service to staff-members' children.

- A health center relocated its visiting rooms and offices to improve client flow.

- One unit built a cafeteria inside the unit, and bought a set of dishes to provide snacks during regular informal staff meetings.

- In one unit, schedules were established for daily staff meetings (mid-morning or midafternoon) in the center's cafeteria to share experiences.

- One unit made obligatory the use of an algorithm to review clients' needs and systematically offer the services they needed. All service delivery units used some sort of procedure to ensure the delivery of integral care services. One unit, for example, created visiting rooms with general-practice doctors to ensure that in all visiting rooms all services were offered. Another unit made sure that all available services were mentioned during consultations.

- One unit hired doctors of both genders for each specialty. In this way they made sure they offered the client the option of selecting their preference for a male or female provider.

- One unit carried out a "mini-media" contest, by grouping staff into five-person teams. Each team had to present posters or murals with key messages on SRH, gender, values, and principles. The three best teams were awarded a dinner paid by the institution, and all posters were framed and hung on the walls in different areas of the unit.

- One unit moved to other offices (another house), with larger and more comfortable spaces.

- Several units created commissions or campaigns to keep things tidy, maintain cleanliness and storage of office items, organize key organizational documents, draw up IEC materials, and develop workshops. These commissions carried out regular internal evaluations.

\section{We can conclude that participating organizations were capable of implementing actions to solve noncompliance with quality and gender standards.}

\section{Do the implemented actions affect compliance with gender and quality standards?}

Table 7 presents the results of follow-up visits and assessments carried out to verify compliance with the standards. The first column shows the self-assessment by each unit without the assessment instruments provided by PROCOSI. The second column shows data collected during the first supervision visit, when the PROCOSI Project Coordinator and the local coordinator used the assessment instruments. Dramatic differences can be seen, and as a consequence of this second assessment, all units had to restate their action plans to guarantee compliance with standards.

The third and fourth columns show the results of the external evaluations carried out for each unit. The first external evaluation was made by PROCOSI central office personnel and project coordinators from other participating units. The second external evaluation was carried out by the PROCOSI Project Coordinator and the FRONTIERS Project Monitor. Data from the first external evaluation show that only one unit failed to comply with the minimum prerequisites to receive the second external evaluation visit. Two units did not have data since they had not 
requested the external evaluation that was made in that round. The second external evaluation shows an overall increase in compliance with standards of quality, except for one service unit where compliance measures declined because a larger sample was applied, providing data that better represented the conditions in the unit. One unit remained without data because it never requested the final external evaluation.

Table 7: $\quad$ Percentage of standards met in the different assessments according to unit

\begin{tabular}{|c|c|c|c|c|}
\hline \multirow[t]{2}{*}{ Unit } & \multicolumn{4}{|c|}{ Percentage of compliance with standards } \\
\hline & $\begin{array}{c}\text { First self- } \\
\text { assessment } \\
\text { without } \\
\text { instruments }\end{array}$ & $\begin{array}{l}\text { Assessment with } \\
\text { instruments }\end{array}$ & $\begin{array}{c}\text { First } \\
\text { external } \\
\text { evaluation }\end{array}$ & $\begin{array}{c}\text { Second } \\
\text { external } \\
\text { evaluation }\end{array}$ \\
\hline \multicolumn{5}{|l|}{ Service delivery units } \\
\hline 1 & 88 & 40 & 91 & 94 \\
\hline 2 & 82 & 20 & 95 & 98 \\
\hline 3 & 75 & 8 & 91 & 98 \\
\hline 4 & 89 & 5 & 94 & 86 \\
\hline 5 & 71 & 22 & 92 & 91 \\
\hline 6 & 42 & 0 & 94 & 91 \\
\hline 7 & 78 & 0 & 97 & 98 \\
\hline 8 & $\mathrm{~N} / \mathrm{D}$ & 14 & $\mathrm{~N} / \mathrm{D}$ & $\mathrm{N} / \mathrm{D}$ \\
\hline Average service delivery units & 75 & 14 & 93 & 94 \\
\hline \multicolumn{5}{|l|}{ Management support units } \\
\hline 1 & 76 & 0 & 76 & 88 \\
\hline 2 & 71 & 6 & 88 & 100 \\
\hline 3 & 76 & 0 & $\mathrm{~N} / \mathrm{D}$ & 100 \\
\hline 4 & 76 & 0 & 94 & 100 \\
\hline 5 & 76 & 0 & 100 & 100 \\
\hline 6 & 65 & 6 & 100 & 100 \\
\hline 7 & 71 & 0 & 100 & 100 \\
\hline Average management support units & 73 & 2 & 93 & 98 \\
\hline
\end{tabular}

Table 8 describes the average improvement in compliance with standards for all of the units according to the type of standard evaluated. As can be seen, on average very large improvements in compliance were achieved, from 8 to 61 indicators for service delivery, and from 0 to 17 for the management support units. For the service delivery units, standards for 'institutional policies and practices' and for 'provider practices' were not completely corrected when the external evaluations were performed, and for management support units, only one unit still had problems with policies and practices. The rest of the standards were completely corrected by all units. 
We conclude that actions by work teams did have an effect on improving compliance with standards of quality proposed by the project.

Table 8: Average changes in standards between baseline (BL) and endline (EL) external evaluations

\begin{tabular}{|c|c|c|c|c|c|}
\hline & & & & $\begin{array}{c}\text { Service delivery } \\
\text { units }\end{array}$ & $\begin{array}{c}\text { Management support } \\
\text { units }\end{array}$ \\
\hline \multirow{16}{*}{$\begin{array}{l}\text { Groups of } \\
\text { standards }\end{array}$} & \multirow{2}{*}{ I } & \multirow{2}{*}{$\begin{array}{l}\text { Policies and } \\
\text { procedures }\end{array}$} & BL & 3 & 0 \\
\hline & & & EL & 13 & 10 \\
\hline & \multirow{2}{*}{ II } & \multirow{2}{*}{ Provider practices } & BL & 4 & \\
\hline & & & EL & 23 & \\
\hline & \multirow{2}{*}{ III } & \multirow{2}{*}{ Personnel knowledge } & BL & 0 & 0 \\
\hline & & & EL & 3 & 2 \\
\hline & \multirow{2}{*}{ IV } & \multirow{2}{*}{ Client Comfort } & $B L$ & 0 & \\
\hline & & & EL & 2 & \\
\hline & \multirow{2}{*}{$\mathbf{V}$} & \multirow{2}{*}{ Client satisfaction } & BL & 1 & 11 \\
\hline & & & EL & 0 & 1 \\
\hline & \multirow{2}{*}{ VI } & \multirow{2}{*}{ Gendered language } & BL & 0 & 0 \\
\hline & & & EL & 2 & 2 \\
\hline & \multirow{2}{*}{ VII } & \multirow{2}{*}{ IEC and training } & BL & 0 & 0 \\
\hline & & & EL & 4 & 2 \\
\hline & \multirow{2}{*}{ VIII } & \multirow{2}{*}{$\begin{array}{l}\text { Monitoring and } \\
\text { evaluation }\end{array}$} & $\mathrm{BL}$ & 0 & \\
\hline & & & EL & 1 & \\
\hline \multirow{2}{*}{\multicolumn{3}{|c|}{ Totals }} & $\mathrm{BL}$ & 8 & 0 \\
\hline & & & EL & 61 & 17 \\
\hline
\end{tabular}

4. What are the costs of achieving certification per unit?

Costs incurred to implement gender and quality improvements can be classified as economic costs (time invested by personnel in carrying out activities) or financial costs (recurrent spending, purchase of goods, improvement of infrastructure and printing and distribution of IEC material). These costs can be summarized as:

1. Costs produced by changes in policies and practices (review of documents, development of policy and practice proposals, presentation meetings, recurrent expenditures)

2. Costs of meetings or workshops (time and expenditure of participants, consultations, time and expenditure of facilitators, administrative support time, recurrent expenditures)

3. Costs of improvement of infrastructure, equipment or furniture (personnel time, purchase of goods, improvement of infrastructure, recurrent spending)

4. Costs of development and distribution of IEC material (personnel time, printing of material, distribution of material, recurrent expenditures)

5. Supervision costs (personnel time, recurrent expenditures). 
A costing guide was created that included instructions for filling out five paper forms to collect this information, and five electronic forms that can be filled out manually or electronically, according to the user's preferences. Table 9 shows that the average $\operatorname{cost}^{5}$ of activities carried out by service delivery units to incorporate the gender perspective in their programs was $\$ 4,184$, while the average cost for management support units was $\$ 2,528$.

Table 9: $\quad$ Costs per Unit (in US\$)

\begin{tabular}{|c|c|c|c|c|}
\hline Unit & $\begin{array}{l}\text { Costs covered } \\
\text { by unit }\end{array}$ & $\begin{array}{l}\text { Costs covered } \\
\text { by PROCOSI }\end{array}$ & Total Costs & $\begin{array}{l}\text { Percentage of } \\
\text { standards met }\end{array}$ \\
\hline \multicolumn{5}{|c|}{ Service delivery units } \\
\hline Unit 1 & 6,085 & 180 & 6,265 & 94 \\
\hline Unit 2 & 1,005 & 180 & 1,185 & 98 \\
\hline Unit 3 & 6,228 & 180 & 6,408 & 98 \\
\hline Unit 4 & 1,256 & 180 & 1,436 & 86 \\
\hline Unit 5 & 315 & 180 & 495 & 91 \\
\hline Unit 6 & 12,535 & 180 & 12,715 & 91 \\
\hline Unit 7 & 603 & 180 & 783 & 98 \\
\hline Unit 8 & Not available & 180 & Not available & 62 \\
\hline Total & 28,027 & 1,440 & 29,287 & \\
\hline \multicolumn{3}{|c|}{ Average cost per service delivery unit } & 4,184 & \\
\hline \multicolumn{5}{|c|}{ Management support units } \\
\hline Unit 1 & 2,629 & 180 & 2,809 & 88 \\
\hline Unit 2 & 1,358 & 180 & 1,538 & 100 \\
\hline Unit 3 & 1,021 & 180 & 1,201 & 100 \\
\hline Unit 4 & 1,464 & 180 & 1,644 & 100 \\
\hline Unit 5 & 3,782 & 180 & 3,962 & 100 \\
\hline Unit 6 & 3,246 & 180 & 3,426 & 100 \\
\hline Unit 7 & 2,938 & 180 & 3,118 & 100 \\
\hline Total & 16,438 & 1,260 & 17,698 & \\
\hline \multicolumn{3}{|c|}{ Average cost per management support unit } & 2,528 & \\
\hline
\end{tabular}

Figure 1 shows that there is no relationship between the cost invested in efforts to incorporate a gender perspective into programs and compliance with standards. For example, two units achieved 91 percent compliance with standards of quality and gender; however, the first one invested a much smaller amount $(\$ 495)$ than the second $(\$ 12,715)$.

$5 \quad$ The costs are presented in US dollars using US $\$ 1=8.02$ Bolivianos as the exchange rate. One of the service delivery units did not report its costs and so was not included when calculating the average. 
Figure 1: Cost ratio according to compliance by accreditation unit

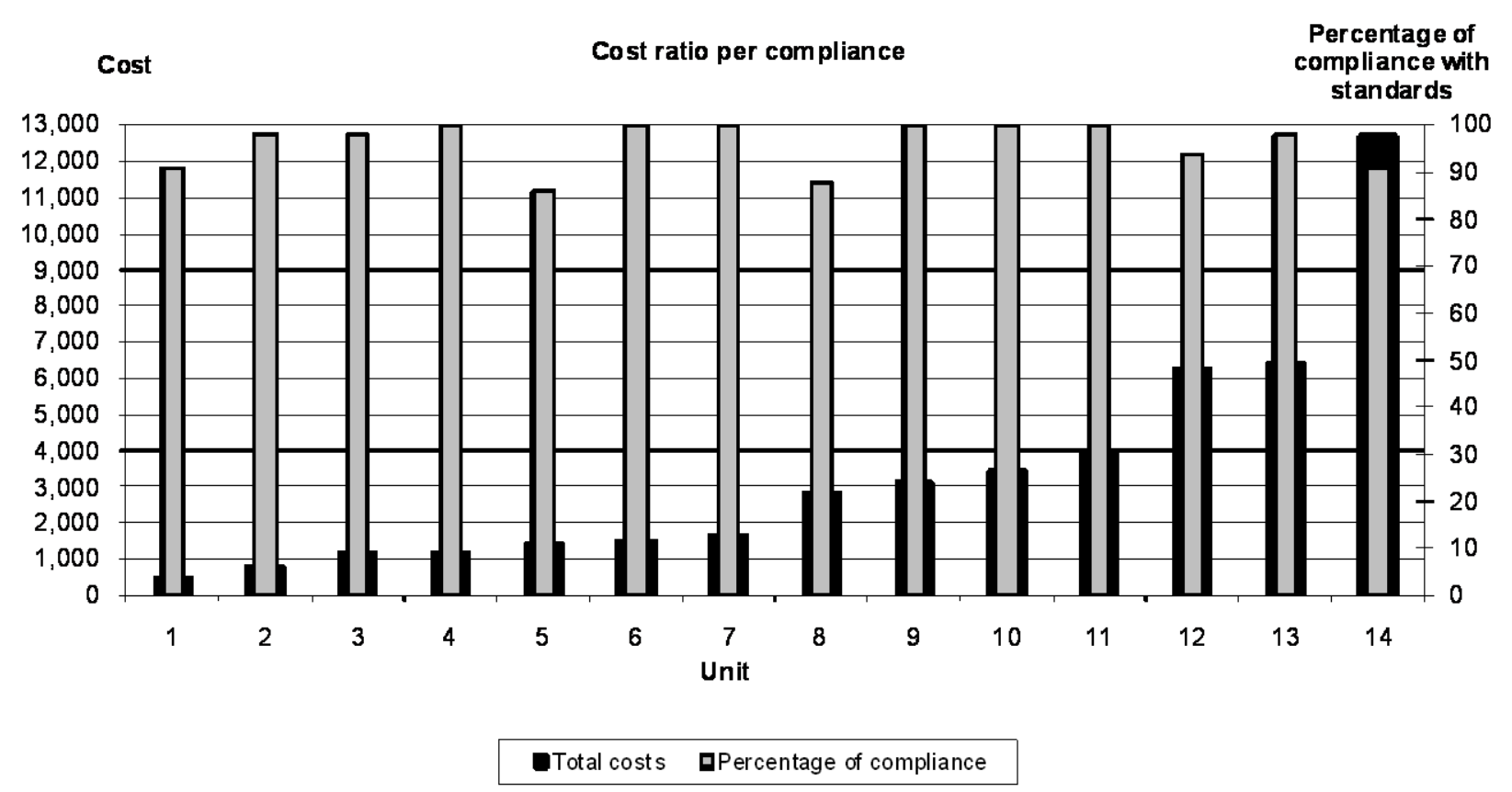

Annex 5 details the costs incurred by each unit and by type of spending. Workshops and meetings accounted for about half of all the costs. For service delivery units, the second highest cost was for implementing improvements in infrastructure, equipment, and furniture, whereas for management support units it was for implementing changes in policies and practices.

Annex 6 allocates the costs to four areas:

- Personnel time (an economic cost that does not represent a financial cost but rather an opportunity cost, since personnel invest time in this project instead of in other activities in the organization)

- Recurrent costs, which include purchase of desk materials for carrying out the activities

- Infrastructure, equipment and furniture (purchase of goods or improvement of facilities)

- IEC materials (printing and distribution of IEC materials).

As can be seen in the totals, both for service delivery units and management support units, the highest proportion is for opportunity costs (personnel time), although as might be expected, this is much greater for management support units (92\%) than for service delivery units (49\%). For service delivery units, the next highest costs were for infrastructure, equipment and furniture (26\%) and recurrent expenses, such as office materials (21\%).

At the beginning of implementation of the action plans, all organizations were sent IEC materials for their distribution to clients and to exhibit in waiting rooms and doctors' offices, and bibliographic support material for the concepts. No new IEC materials were produced; instead, copies were reproduced using existing materials. Reproduction and distribution costs were divided equally among organizations that received the material. 


\section{DISSEMINATION AND UTILIZATION}

Communication of the results took place at a National Certification Ceremony and at two dissemination workshops. Two hundred copies of the four implementation guides were printed for attendees at the National Certification Ceremony and for participants of both dissemination workshops.

The fist dissemination workshop was carried out in April 2007. The objective of this three-hour workshop was to present the strategy, the results and the experiences of participating units to USAID, the Ministry of Health (Health Reform Program), SEDES La Paz, PROCOSI, AMUPEI, Movimiento Manuela Ramos, EngenderHealth, Promujer, CEMSE and IPTK. As a result of this workshop, SEDES La Paz expressed interest in replicating the experience as a pilot project in four hospitals with maternity wards in La Paz and El Alto, not necessarily as a certification experience (since the Ministry of Health had not yet developed an official procedure for this state recognition), but to ensure the incorporation of a gender perspective into the centers selected. SEDES La Paz requested technical assistance from FRONTIERS and the SEDES representative participated in a regional workshop in Costa Rica in June 2007 for disseminating these findings (see below) to receive direct technical assistance.

The second dissemination workshop also took place in April 2007. The aim of this one-day workshop was to present the results of the intervention and to promote participants' interest in replicating the experience. Representatives were invited from NGOs affiliated to the PROCOSI network interested in applying the strategy to be certified by the network. PROCOSI has committed to institutionalizing this certification process and has underlined the importance of the certification to be considered for proposals and activities within the network. Twenty-two participants from different NGOs attended.

The library (CEDOSI) and the PROCOSI website (www.procosi.org.bo) have made available the four reference guides that explain the certification strategy.

To further utilization of this gender and quality certification strategy, a training workshop for managers from organizations in different countries was held in Costa Rica in June 2007. To facilitate replication of the strategy, FRONTIERS is providing technical assistance for implementing the assessments and adapting the strategy to existing conditions at the participating organizations. 


\section{CONCLUSIONS AND RECOMMENDATIONS}

The evaluation of the gender and quality certification strategy allows us to make the following conclusions:

1. With regard to the interest of NGOs in testing and establishing systems to provide quality services with a gender perspective, slightly more than half (14) of the 26 units originally invited to participate in the project accepted the invitation and concluded the activity. This is despite not providing financial support for activities beyond the initial training, which suggests a definite and committed interest. However, a significant proportion of units could not have participated if no financing at all had been provided.

2. The evaluation confirmed that the NGOs can identify their lack of compliance with proposed standards of quality and gender; to do so, however, they need to use the instruments developed by FRONTIERS and PROCOSI rather than rely on the perceptions and opinions of members of their team since these give a far more lenient view of the real conditions for the service supplied.

3. Team members have no problems in proposing actions that will allow them to improve compliance with standards, and they are able to implement most or all of proposed actions.

4. Implementation of the actions identified by in-facility work teams improves compliance with gender and quality standards, according to objective measurements made with project instruments by external evaluators.

5. The certification strategy is more cost-effective than the previous approach to improving attention to gender. On average each service delivery unit spent $\$ 4,184$ in implementing the activities and achieving their certification-less than one-fifth of the average cost observed in the previous project. Over half of the costs were opportunity costs resulting from the time used by the work team members.

Drawing from the lessons learned by implementing and evaluating this strategy, the following recommendations can be made concerning its future utilization:

- Self-assessments carried out by organizations that seek accreditation are not always trustworthy, even when carried out with instruments specifically designed for this purpose. Assessments must be supervised by a person from outside the NGO that seeks certification. We recommend that a person who is not a member of the center's work team (for example, a supervisor from headquarters) be assigned to follow up self-assessment activities.

- The external evaluation committee must be made up of people with an interest in maintaining the strategy in the future, and preferably by people within the same health network. The original intention to incorporate representatives of national and international organizations in the external evaluation committee did not work as they did not have enough time, but it is important to keep such people informed to enhance dissemination, create a professional climate, and increase the perceived value of the certification. 
- Health centers were more interested in receiving a plaque of merit to mount in their clinic than in carrying out a public certification ceremony. The bigger the plaque of merit the better, since it is a reminder of the efforts made as well as a means for the clients to be aware of the guarantee of quality offered by the organization.

- When the first certification round is finished, the health network must ensure the continuity of future certification processes. In view of the success of NGOs that participated in this strategy, other PROCOSI affiliates have shown much interest in receiving certification. Although PROCOSI has assured them that it will maintain a strategy and continue certifying, a continuous process has not yet been established for future certifications, which might lead organizations that have already achieved certification to lose interest in further certification. 


\section{ANNEXES}

\section{Annex 1: Contents of implementation guides}

\section{Guide for procedures}

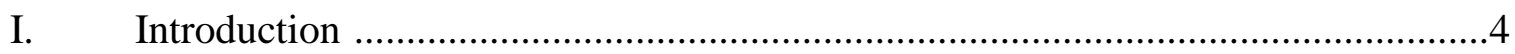

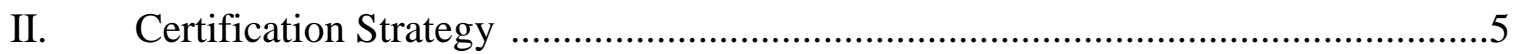

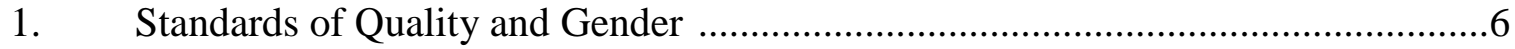

2. Structuring of the Work Team ……………..................................................11

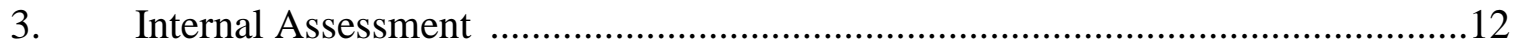

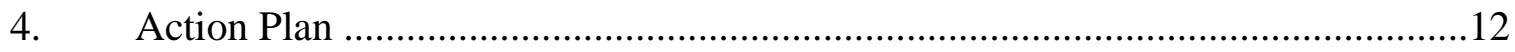

5. Implementation and Strengthening of Actions ..................................................14

6. Second Internal Assessment …………………......................................15

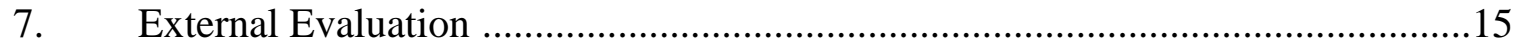

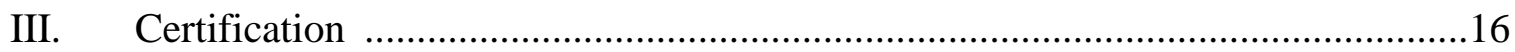

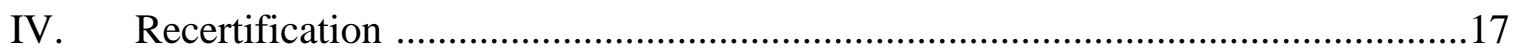

\section{Self-training guide}

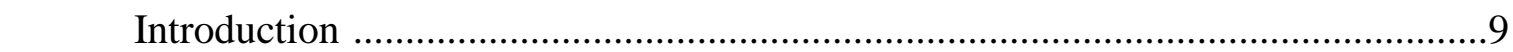

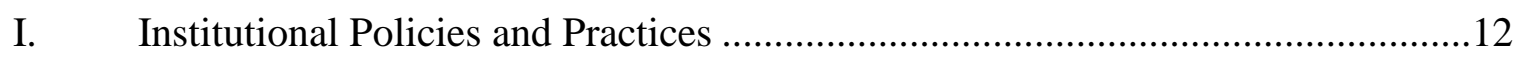

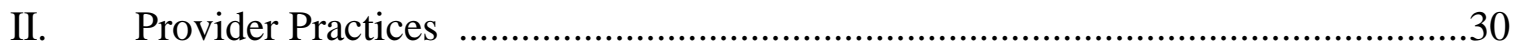

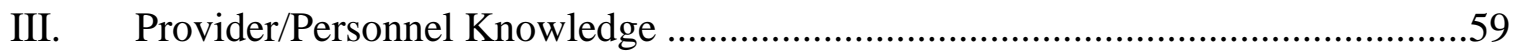

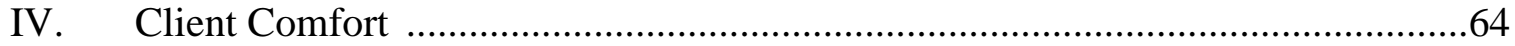

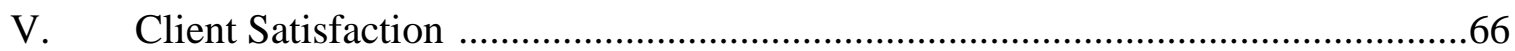

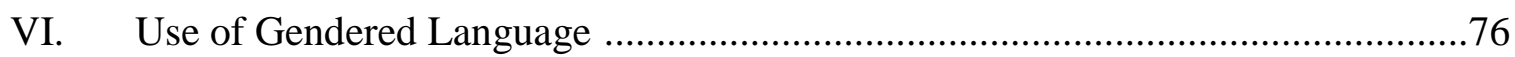

VII. Information, Education, Communication and Training …………........................78

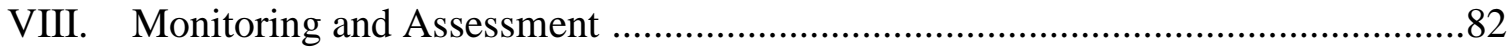

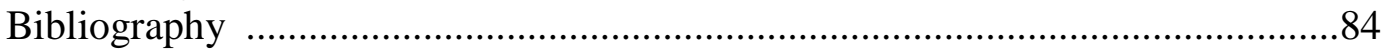

\section{Assessment guide}

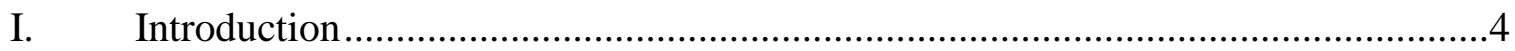

II. Internal and External Evaluation .................................................................

1. Standards of Quality With a Gender Perspective ...................................................

2. Assessment Instruments ..............................................................................

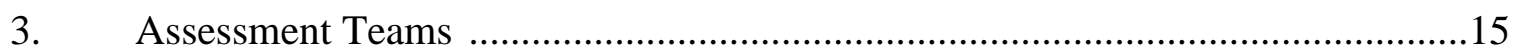

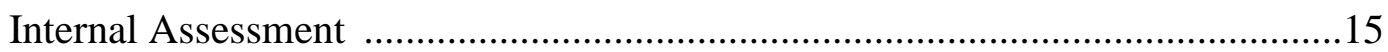

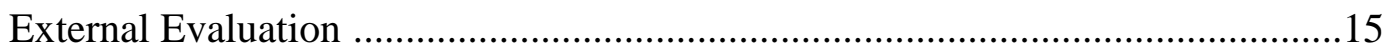

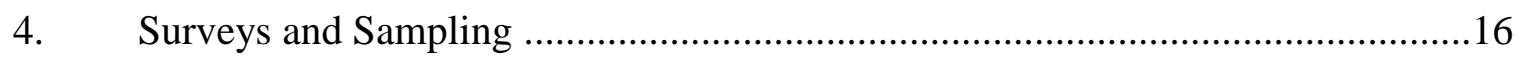

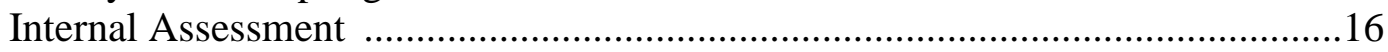

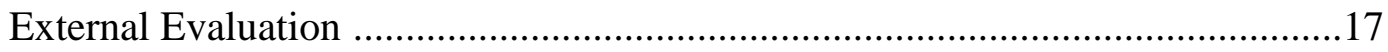

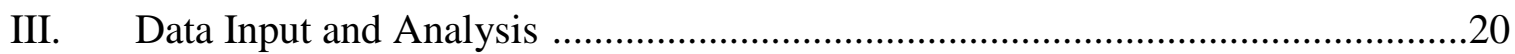

IV. Assessment and Certification Report ……….............................................25

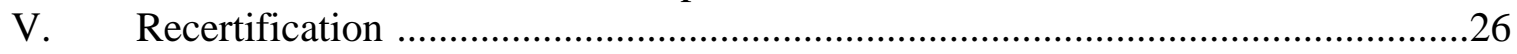




\section{Costs guide}

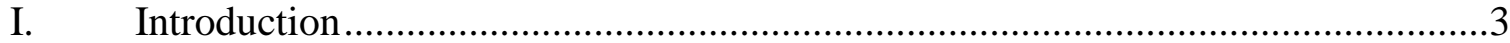

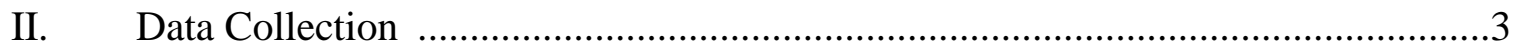

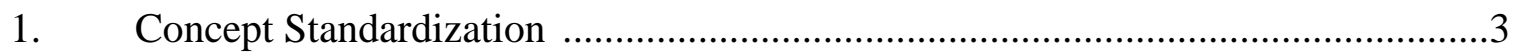

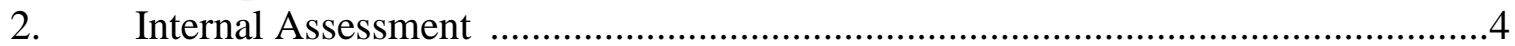

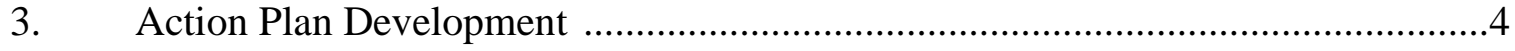

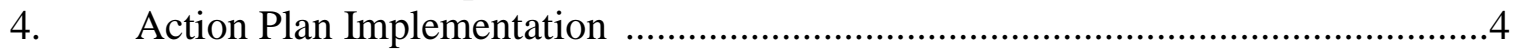

III. Data Collection Forms on Costs …..............................................................

Costs for institutional policies and practices .......................................................5

Costs for meetings/workshops ...................................................................

Costs for infrastructure and equipment improvements ....................................11

Costs for production and distribution of IEC materials] ......................................16

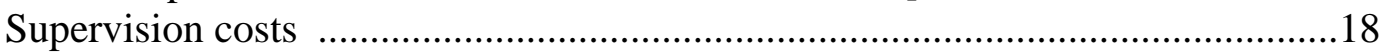

IV. ANNEXES

Annex 1. Definitions

Annex 2. Action Plan Templates

Annex 3. Comprehensive Health Service Delivery Checklist

Annex 4. Internal/External Evaluation Forms

Annex 5. Quality and Gender Standards Table

Annex 6. Evaluation Timeline

Annex 7. Evaluation Templates

Annex 8. Information System Forms

Annex 9. Costs Forms

Annex 10. Annualization Factors

Annex 11. Costs Activities Memory Aids

Annex 12. IPPF/Bolivia Quality Indicators 


\section{Annex 2: $\quad$ List of quality standards}

\section{Standards for management units}

\section{Institutional Policies and Practices}

I.1 The institution's policies include a declaration that promotes women's empowerment

I.2 The institution's policies include a declaration that prohibits gender-based discrimination

I.3 The institution's policies include a declaration that prohibits gender-based discrimination in terms of personnel promotion

I.4 The institution's policies include a declaration that prohibits the abuse of power

I.5 At least 80 percent of the personnel feel that the institution's managers are receptive to their opinions and suggestions

I.6 At least 80 percent of the personnel feel that their recommendations are implemented

I.7 At least 80 percent of the personnel feel motivated to offer opinions/suggestions

I.8 At least 80 percent of the personnel feel that the institution has a collective and teamwork environment

I.9 At least 80 percent of the personnel feel that the institution is receptive to explanations for leaving work when required by family reasons

I.10 Less than 20 percent of the personnel feel that the institution gives preferential treatment to a particular sex

\section{Personnel knowledge}

III.1 Al least 80 percent of the personnel know the definition of sexual and reproductive health

III.3 Al least 80 percent of the personnel know the definition of gender

V Personnel satisfaction

V.2 Conditions of cleanliness and comfort are satisfactory

VI Use of gendered language

VI.1 Non-discriminatory language is used

VI.2 Inclusive language is used

VII Information, education, communication, and training

VII.1 The institution has IEC and training material with information on sexual and reproductive rights, client rights, and women's rights

VII.2 The institution has IEC and training materials with information on sexual and reproductive health 


\section{Standards for service delivery units}

\section{Institutional Policies and Practices}

I.1 The health center's policies include a declaration that promotes women's empowerment

I.2 The health center's policies include a declaration that prohibits gender-based discrimination

I.3 The health center's policies include a declaration that prohibits gender-based discrimination in terms of personnel promotion

I.4 The health center's policies include a declaration that prohibits the abuse of power in the health center

I.5 At least 80 percent of the personnel feel that the health center's managers are receptive to their opinions and suggestions

I.6 At least 80 percent of the personnel feel that their recommendations are implemented

I.7 At least 80 percent of the personnel feel motivated to offer opinions/suggestions

I.8 At least 80 percent of the personnel feel that the health center has a collective and teamwork environment

I.9 At least 80 percent of the personnel feel that the health center is receptive to explanations for leaving work when required by family reasons

I.10 Less than 20 percent of the personnel feel that the health center gives preferential treatment to a particular sex

I.11 At least 50 percent of the sexual and reproductive health services are offered to couples

I.12 The health center's policies include a declaration that establishes counseling services as institutional policy

I.13 The health center does not require the partner's consent for any service

I.14 There is a range of contraceptive methods according to the health center's norms

\section{Provider practices}

II.1 At least 80 percent of providers greet clients

II.2 At least 80 percent of providers wear a visible nametag

II.3 At least 80 percent of providers treat clients respectfully

II.4 At least 80 percent of providers explore sexual and reproductive health topics during consultations

II.5 At least 80 percent of providers explore aspects related to the client's sexual health

II.6 Less than 20 percent of providers feel that RHS topics are not explored due to barriers

II.7 At least 80 percent of providers use didactic material (drawings, pamphlets, flip-chart or other material) to reinforce explanations

II.8 At least 80 percent of providers communicate with the client through simple language

II.9 At least 80 percent of providers explain the details of the diagnosis

II.10 At least 80 percent of providers explain treatment details to the clients

II.11 At least 80 percent of providers look directly at the client while explaining the diagnosis or treatment

II.12 At least 80 percent of providers ask the clients if she or he had questions or doubts

II.13 At least 80 percent of providers answer questions or clear client's doubts

II.14 At least 80 percent of providers explain what they do during a physical exam (including pelvic exam) 
II.15 At least 80 percent of providers provide information or educational materials (pamphlets, leaflets, or others) for the client to take home

II.16 Less than 20 percent of providers say that there is more than half an hour waiting period between the moment the providers arrive to the health center, and the moment they begin attending clients

II.17 Less than 20 percent of clients say that they waited more than 30 minutes to be received by the provider

II.18 At least 80 percent of providers can identify the sexual and reproductive health services offered by the health center

II.19 At least 80 percent of providers dedicate all his/her time to the client without interruptions

II.20 At least 80 percent of providers know and promote the use of dual protection

II.21 At least 80 percent of providers know and promote Pap smears

II.22 At least 80 percent of providers know and promote breast self-examination

II.23 At least 80 percent of providers ask clients about their therapeutic goals

II.24 At least 80 percent of providers determine times according to client traditions and knowledge

II.25 At least 80 percent of providers keep doors and windows closed to avoid air currents during the consultation

II.26 At least 80 percent of providers respect the symbolic practices of the clients

II.27 No provider transmits value judgments about the clients' hygiene

II.28 At least 80 percent of providers talk and understand the region's most used native languages

\section{Provider knowledge}

III.1 Al least 80 percent of personnel know the definition of sexual and reproductive health

III.2 Al least 80 percent of personnel know the contraceptive methods available at the health center

III.3 Al least 80 percent of personnel know the definition of gender

\section{Client comfort}

IV.1 Less than 20 percent of clients say that they had gender-related problems in getting to the health center

IV.2 The health center has resources to attend and entertain minors accompanying clients who go to the health center

\section{Client satisfaction}

V.1 The health center has worked on mechanisms to gather the opinions of clients on office hours and general client satisfaction

V.2 The conditions of cleanliness and comfort are satisfactory

V.3 Equipment is available and in good condition

V.4 The health center ensures conditions for client confidentiality and privacy

V.5 The health center has enough seats for clients in waiting area

V.6 At least 80 percent of the clients feel comfortable talking with providers

V.7 At least 80 percent of the clients feel comfortable asking questions to providers 
V.8 At least 80 percent of the clients consider that time with service provider was sufficient

V.9 At least 80 percent of the clients say that they were well treated by the health center's personnel

V.10 At least 80 percent of the clients were received by a provider of their preference (male or female)

V.11 At least 80 percent of the clients consider that the health center's service hours fit into the clients' needs (gender related)

\section{Use of gendered language}

VI.1 Non-discriminatory language is used

VI.2 Inclusive language is used

VII Information, education, communication, and training

VII.1 The health center has IEC and training material with information on sexual and reproductive rights, client rights, and women's rights

VII.2 The health center has IEC and training materials with information on sexual and reproductive health

VII.3 The health center has visual and/or accessible information about services, service hours, and costs

VII.4 The health center carries out educational activities for clients in waiting area

\section{Monitoring and evaluation}

VIII.1 The health center has a mechanism to establish programmatic changes on the basis of information obtained from clients 
Annex 3: Unmet standards and actions suggested to improve them

\begin{tabular}{|c|c|c|c|}
\hline Unmet standards & $\begin{array}{l}\text { Total actions to } \\
\text { improve } \\
\text { standards }\end{array}$ & Solutions suggested & $\begin{array}{c}\text { Number of } \\
\text { units that } \\
\text { suggested } \\
\text { solution }\end{array}$ \\
\hline \multicolumn{4}{|l|}{ Service delivery units } \\
\hline $\begin{array}{l}\text { I. } 1 \text { There is a statement in } \\
\text { place that promotes } \\
\text { women's empowerment }\end{array}$ & 5 & $\begin{array}{l}\text { - Review institutional documents } \\
\text { - Write a statement of women's } \\
\text { empowerment in institutional } \\
\text { documents. } \\
\text { - Disseminate the statement in the } \\
\text { institution. } \\
\text { - Hold informative meetings with the } \\
\text { Management Council for decision- } \\
\text { making } \\
\text { - Adapt documents }\end{array}$ & $\begin{array}{l}8 \\
8 \\
7 \\
\\
1 \\
1\end{array}$ \\
\hline $\begin{array}{l}\text { I.11 At least } 50 \% \text { of sexual } \\
\text { and reproductive health visits } \\
\text { are offered to couples }\end{array}$ & 8 & $\begin{array}{l}\text { - Promote the attendance of couples to } \\
\text { - Add one check box in counseling } \\
\text { service forms on this subject for } \\
\text { adequate monitoring } \\
\text { - Review the preceding management's } \\
\text { information system } \\
\text { - Presentation and analysis of results with } \\
\text { health personnel } \\
\text { - Definition of strategies for compliance } \\
\text { with indicator } \\
\text { - Implement a registry of visits for single } \\
\text { women, single men and couples. } \\
\text { - Promote consultation for couples } \\
\text { - Begin implementation again of record of } \\
\text { couples that attend consultations in } \\
\text { notebook № } 1 \text { of the National Service } \\
\text { Information System }\end{array}$ & $\begin{array}{l}1 \\
5 \\
1 \\
1 \\
1 \\
6 \\
8 \\
1\end{array}$ \\
\hline $\begin{array}{l}\text { II. } 2 \text { At least } 80 \% \text { of providers } \\
\text { wear a visible nametag }\end{array}$ & 4 & $\begin{array}{l}\text { - Display permanent nametag, even } \\
\text { during home visits } \\
\text { - Instructive for use nametags } \\
\text { - Make nametags for new personnel } \\
\text { - Make nametags for health providers and } \\
\text { managers }\end{array}$ & $\begin{array}{l}1 \\
8 \\
1 \\
7\end{array}$ \\
\hline $\begin{array}{l}\text { II.5 At least } 80 \% \text { of providers } \\
\text { explore aspects related to } \\
\text { clients' sexual health during } \\
\text { consultations/counseling } \\
\text { sessions }\end{array}$ & 5 & $\begin{array}{l}\text { - Personnel evaluated internally by the } \\
\text { organization, along with other aspects } \\
\text { related to services and benefits } \\
\text { - Application of monitoring instrument to } \\
\text { measure the reach of the indicator } \\
\text { - Presentation and analysis of results with } \\
\text { health personnel. } \\
\text { - One-day conferences for reflecting on } \\
\text { and evaluating the indicator with health } \\
\text { personnel } \\
\text { - Observation visits during consultations } \\
\text { every two months }\end{array}$ & $\begin{array}{l}6 \\
2 \\
6 \\
1 \\
1\end{array}$ \\
\hline
\end{tabular}




\begin{tabular}{|c|c|c|c|}
\hline Unmet standards & $\begin{array}{l}\text { Total actions to } \\
\text { improve } \\
\text { standards }\end{array}$ & Solutions suggested & $\begin{array}{c}\text { Number of } \\
\text { units that } \\
\text { suggested } \\
\text { solution }\end{array}$ \\
\hline $\begin{array}{l}\text { II.7 At least } 80 \text { percent of } \\
\text { providers use didactic } \\
\text { material (drawings, } \\
\text { brochures, flipcharts or other } \\
\text { material) to reinforce their } \\
\text { explanations in counseling } \\
\text { sessions/consultations }\end{array}$ & 5 & $\begin{array}{l}\text { - Personnel evaluated internally by the } \\
\text { organization, along with other aspects } \\
\text { related to services and benefits } \\
\text { - Provide didactic support material for } \\
\text { medical exam rooms } \\
\text { - Observation of provider to verify use of } \\
\text { didactic materials } \\
\text { - User survey } \\
\text { - Review existing material to order up-to- } \\
\text { date material and provide it to each } \\
\text { medical exam room }\end{array}$ & $\begin{array}{l}6 \\
8 \\
6 \\
3 \\
1\end{array}$ \\
\hline $\begin{array}{l}\text { II.9 At least } 80 \text { percent of } \\
\text { providers explain details of } \\
\text { the diagnosis to the client } \\
\text { during } \\
\text { consultations/counseling } \\
\text { sessions }\end{array}$ & 4 & $\begin{array}{l}\text { - Personnel evaluated internally by the } \\
\text { organization, along with other aspects } \\
\text { related to services and benefits } \\
\text { - Application of monitoring instruments to } \\
\text { measure reach of indicator } \\
\text { - Presentation and analysis of results with } \\
\text { - } \text { - One-dalth personnel. } \\
\text { and evaluating the indicator with health } \\
\text { personnel }\end{array}$ & $\begin{array}{l}6 \\
3 \\
6 \\
1\end{array}$ \\
\hline $\begin{array}{l}\text { II. } 14 \text { At least } 80 \text { percent of } \\
\text { providers explain what they } \\
\text { are doing during the physical } \\
\text { exam or pelvic exam }\end{array}$ & 4 & $\begin{array}{l}\text { - Awareness-raising workshops with } \\
\text { health personnel for compliance with } \\
\text { indicator } \\
\text { - Application of monitoring instruments to } \\
\text { measure reach of indicator } \\
\text { - Presentation and analysis of results with } \\
\text { health personnel. } \\
\text { - One-day conferences for reflecting on } \\
\text { and evaluating the indicator with health } \\
\text { personnel }\end{array}$ & $\begin{array}{l}4 \\
6 \\
6 \\
6\end{array}$ \\
\hline $\begin{array}{l}\text { II. } 15 \text { At least } 80 \text { percent of } \\
\text { providers provide the client } \\
\text { with reinforcement } \\
\text { educational material }\end{array}$ & 7 & $\begin{array}{l}\text { - Delivery of informative or educational } \\
\text { materials to services (consultation } \\
\text { rooms) } \\
\text { - Distribution of educational material to } \\
\text { users in consultations and counseling } \\
\text { sessions } \\
\text { - Verify that IEC materials are being } \\
\text { given to clients through exit interviews } \\
\text { - Creation and approval of material } \\
\text { - Printing of material } \\
\text { - Distribution of IEC material to } \\
\text { - Pxamination rooms } \\
\text { Provide examination rooms with } \\
\text { brochure holders built from local } \\
\text { materials }\end{array}$ & $\begin{array}{l}4 \\
2 \\
3 \\
2 \\
6 \\
1\end{array}$ \\
\hline
\end{tabular}




\begin{tabular}{|c|c|c|c|}
\hline Unmet standards & $\begin{array}{l}\text { Total actions to } \\
\text { improve } \\
\text { standards }\end{array}$ & Solutions suggested & $\begin{array}{c}\text { Number of } \\
\text { units that } \\
\text { suggested } \\
\text { solution }\end{array}$ \\
\hline $\begin{array}{l}\text { II.16 Less than } 20 \text { percent of } \\
\text { providers say there is a } \\
\text { delay of over half an hour } \\
\text { from the time health } \\
\text { personnel arrive at to the } \\
\text { health facility to the moment } \\
\text { in which clients are attended }\end{array}$ & 3 & $\begin{array}{l}\text { - Interview with doctors. } \\
\text { - Greater self-control in entrance hours } \\
\text { - Carry out a meeting to analyze the } \\
\text { distribution order numbers given out for } \\
\text { outpatient visits according to schedules } \\
\text { established by the institution }\end{array}$ & $\begin{array}{l}5 \\
7 \\
1\end{array}$ \\
\hline $\begin{array}{l}\text { II. } 17 \text { Less than } 20 \text { percent of } \\
\text { clients say they waited over } \\
\text { half an hour to be attended }\end{array}$ & 3 & $\begin{array}{l}\text { - Development and implementation of an } \\
\text { observation instrument } \\
\text { - Development of an immediate service to } \\
\text { clients strategy plan } \\
\text { - Organize user attendance by assigning } \\
\text { an approximate entrance hour for their } \\
\text { consultation according to the number } \\
\text { they have }\end{array}$ & $\begin{array}{l}8 \\
1 \\
2\end{array}$ \\
\hline $\begin{array}{l}\text { II.19 At least } 80 \text { percent of } \\
\text { providers dedicate the whole } \\
\text { time to the client without } \\
\text { interruptions during } \\
\text { consultations/counseling } \\
\text { services }\end{array}$ & 6 & $\begin{array}{l}\text { - Application of monitoring instruments to } \\
\text { measure reach of indicator } \\
\text { - One-day conferences for reflecting on } \\
\text { and evaluating the indicator with health } \\
\text { personnel for decision-making } \\
\text { - Creation of new service guidelines } \\
\text { - Writing of instruction manual } \\
\text { - Preparation of DO NOT INTERRUPT } \\
\text { sign for the provider to place on his or } \\
\text { her door } \\
\text { - Write down messages and give them to } \\
\text { the doctor along with the clinical records } \\
\text { for him or her to organize their return }\end{array}$ & $\begin{array}{l}7 \\
6 \\
2 \\
4 \\
1 \\
1\end{array}$ \\
\hline $\begin{array}{l}\text { II.20 At least } 80 \text { percent of } \\
\text { personnel know and promote } \\
\text { the use of the dual protection } \\
\text { method }\end{array}$ & 4 & $\begin{array}{l}\text { - Survey of health personnel to measure } \\
\text { the reach of the indicator } \\
\text { - One-day conferences for reflecting on } \\
\text { and evaluating the indicator with health } \\
\text { personnel } \\
\text { - Hold exchange of knowledge meetings } \\
\text { with health personnel on the subject } \\
\text { - Carry out training workshops on the } \\
\text { dual protection method }\end{array}$ & $\begin{array}{l}7 \\
6 \\
4 \\
4\end{array}$ \\
\hline $\begin{array}{l}\text { II.21 At least } 80 \text { percent of } \\
\text { personnel know and promote } \\
\text { the Pap smear }\end{array}$ & 4 & $\begin{array}{l}\text { - Survey of health personnel to measure } \\
\text { the reach of the indicator } \\
\text { - One-day conferences for reflecting on } \\
\text { and evaluating the indicator with health } \\
\text { personnel } \\
\text { - Hold exchange of knowledge meetings } \\
\text { with health personnel on the subject } \\
\text { - Raise awareness on the importance of } \\
\text { providing knowledge }\end{array}$ & $\begin{array}{l}6 \\
6 \\
4 \\
3\end{array}$ \\
\hline
\end{tabular}




\begin{tabular}{|c|c|c|c|}
\hline Unmet standards & $\begin{array}{l}\text { Total actions to } \\
\text { improve } \\
\text { standards }\end{array}$ & Solutions suggested & $\begin{array}{c}\text { Number of } \\
\text { units that } \\
\text { suggested } \\
\text { solution }\end{array}$ \\
\hline $\begin{array}{l}\text { II.22 At least } 80 \text { percent of } \\
\text { personnel know and promote } \\
\text { breast self-examination }\end{array}$ & 5 & $\begin{array}{l}\text { - Survey of health personnel to measure } \\
\text { the reach of the indicator } \\
\text { - One-day conferences for reflecting on } \\
\text { and evaluating the indicator with health } \\
\text { personnel } \\
\text { - Hold exchange of knowledge meetings } \\
\text { with health personnel on the subject } \\
\text { - Further training workshops on breast } \\
\text { self-examination } \\
\text { - Raise awareness on the importance of } \\
\text { providing knowledge }\end{array}$ & $\begin{array}{l}6 \\
6 \\
4 \\
4 \\
3\end{array}$ \\
\hline $\begin{array}{l}\text { II.24 At least } 80 \text { percent of } \\
\text { personnel set times } \\
\text { according to client customs } \\
\text { and knowledge }\end{array}$ & 5 & $\begin{array}{l}\text { - Provide training on the subject on } \\
\text { contextualization of consultation and } \\
\text { later evaluation. } \\
\text { - Application of monitoring instruments to } \\
\text { measure reach of indicator } \\
\text { - Provide Bristol almanac } \\
\text { - Train on use of Bristol almanac } \\
\text { - Workshop on importance of indicator }\end{array}$ & $\begin{array}{l}8 \\
6 \\
1 \\
1\end{array}$ \\
\hline $\begin{array}{l}\text { II. } 25 \text { At least } 80 \text { percent of } \\
\text { personnel keep doors and } \\
\text { windows shut to prevent air } \\
\text { currents during consultation }\end{array}$ & 2 & $\begin{array}{l}\text { - Internal evaluation of health personnel } \\
\text { made by the organization, alongside } \\
\text { other aspects related to services and } \\
\text { benefits. } \\
\text { - Improve outpatient consultations and } \\
\text { counseling environments ensuring they } \\
\text { have all necessary material for } \\
\text { maintaining privacy during the } \\
\text { consultation }\end{array}$ & 6 \\
\hline $\begin{array}{l}\text { II.26 At least } 80 \text { percent of } \\
\text { personnel respect clients' } \\
\text { symbolic practices }\end{array}$ & 4 & $\begin{array}{l}\text { - Internal evaluation of health personnel } \\
\text { made by the organization, alongside } \\
\text { other aspects related to services and } \\
\text { benefits. } \\
\text { - Application of monitoring instruments to } \\
\text { measure the reach of the indicator } \\
\text { - One-day conferences for reflecting on } \\
\text { and evaluating the indicator with health } \\
\text { personnel } \\
\text { - Planning of observation visits during } \\
\text { consultations every two months }\end{array}$ & $\begin{array}{l}6 \\
6 \\
6 \\
1\end{array}$ \\
\hline
\end{tabular}




\begin{tabular}{|c|c|c|c|}
\hline Unmet standards & $\begin{array}{l}\text { Total actions to } \\
\text { improve } \\
\text { standards }\end{array}$ & Solutions suggested & $\begin{array}{c}\text { Number of } \\
\text { units that } \\
\text { suggested } \\
\text { solution }\end{array}$ \\
\hline $\begin{array}{l}\text { III.3 At least } 80 \text { percent of } \\
\text { personnel know the definition } \\
\text { of gender }\end{array}$ & 6 & $\begin{array}{l}\text { - Training and retraining on topics found } \\
\text { in the self-learning modules of Sexual } \\
\text { and Reproductive Health, which will be } \\
\text { evaluated } \\
\text { - Carrying out workshops } \\
\text { - Survey made with health personnel to } \\
\text { measure the reach of the indicator } \\
\text { - One-day conferences for reflecting on } \\
\text { and evaluating the indicator with health } \\
\text { personnel } \\
\text { - Holding knowledge exchange meetings } \\
\text { with health personnel on the subject } \\
\text { - Training workshops }\end{array}$ & $\begin{array}{l}6 \\
8 \\
6 \\
6 \\
1 \\
1\end{array}$ \\
\hline $\begin{array}{l}\text { V.2 Conditions of cleanliness } \\
\text { and comfort are satisfactory }\end{array}$ & 6 & $\begin{array}{l}\text { - Observation of health center } \\
\text { - Provider surveys } \\
\text { - User surveys } \\
\text { - Drawing up of messages for raising } \\
\text { awareness among users for keeping the } \\
\text { area clean and tidy. } \\
\text { - User satisfaction exit surveys. } \\
\text { - Suggestions box in admittance areas } \\
\text { and consultations }\end{array}$ & $\begin{array}{l}1 \\
6 \\
6\end{array}$ \\
\hline $\begin{array}{l}\text { V.3 Equipment is available } \\
\text { and in good shape }\end{array}$ & 4 & $\begin{array}{l}\text { - Review of inventory of last management } \\
\text { - Maintenance and replacement of } \\
\text { medical equipment and instruments } \\
\text { - Execute maintenance plan for } \\
\text { equipment programmed in the Annual } \\
\text { Operational Plan in each service } \\
\text { - Systematic observation of optimal } \\
\text { functioning conditions of equipment }\end{array}$ & $\begin{array}{l}1 \\
3 \\
1 \\
3\end{array}$ \\
\hline $\begin{array}{l}\text { V.4 Conditions ensure } \\
\text { confidentiality and privacy of } \\
\text { the client }\end{array}$ & 3 & $\begin{array}{l}\text { - Permanent evaluation of health } \\
\text { personnel on the importance of privacy } \\
\text { - Internal evaluation of personnel by the } \\
\text { organization, as well as of other aspect } \\
\text { related to services and benefits } \\
\text { - Improving counseling environment by } \\
\text { ensuring they have the necessary } \\
\text { material to maintain privacy during the } \\
\text { session }\end{array}$ & $\begin{array}{l}5 \\
6\end{array}$ \\
\hline $\begin{array}{l}\text { V.7 At least } 80 \text { percent of } \\
\text { clients feel comfortable } \\
\text { asking questions and } \\
\text { clearing up doubts with } \\
\text { providers }\end{array}$ & 4 & $\begin{array}{l}\text { - Internal evaluation of health personnel } \\
\text { made by the organization, alongside } \\
\text { other aspects related to services and } \\
\text { benefits. } \\
\text { - Observation of providers } \\
\text { - User surveys } \\
\text { - One-day conferences for reflecting on } \\
\text { and evaluating the indicator with health, } \\
\text { management and support personnel }\end{array}$ & $\begin{array}{l}6 \\
2 \\
8 \\
6\end{array}$ \\
\hline
\end{tabular}




\begin{tabular}{|c|c|c|c|}
\hline Unmet standards & $\begin{array}{l}\text { Total actions to } \\
\text { improve } \\
\text { standards }\end{array}$ & Solutions suggested & $\begin{array}{l}\text { Number of } \\
\text { units that } \\
\text { suggested } \\
\text { solution }\end{array}$ \\
\hline $\begin{array}{l}\text { V. } 8 \text { At least } 80 \text { percent of } \\
\text { clients consider that the time } \\
\text { they spend in consultation is } \\
\text { enough }\end{array}$ & 2 & $\begin{array}{l}\text { - User surveys } \\
\text { - Internal evaluation of health personnel } \\
\text { made by the organization, alongside } \\
\text { other aspects related to services and } \\
\text { benefits. }\end{array}$ & 6 \\
\hline $\begin{array}{l}\text { V.10 At least } 80 \text { percent of } \\
\text { clients were seen by a } \\
\text { person of the sex of their } \\
\text { preference }\end{array}$ & 3 & $\begin{array}{l}\text { - User surveys } \\
\text { - Development of report, communication } \\
\text { of results and decision-making } \\
\text { - Implementation of user care guidelines }\end{array}$ & $\begin{array}{l}8 \\
5 \\
3\end{array}$ \\
\hline $\begin{array}{l}\text { V. } 11 \text { At least } 80 \text { percent of } \\
\text { clients consider that office } \\
\text { hours adapt to their (gender- } \\
\text { related) needs }\end{array}$ & 4 & $\begin{array}{l}\text { - User surveys } \\
\text { - Analysis of results } \\
\text { - One-day conferences for reflecting on } \\
\text { and evaluating the indicator with health } \\
\text { personnel } \\
\text { - Review of office hours }\end{array}$ & $\begin{array}{l}8 \\
8 \\
6 \\
1\end{array}$ \\
\hline $\begin{array}{l}\text { VI.1 Non-discriminatory } \\
\text { language is used }\end{array}$ & 6 & $\begin{array}{l}\text { - Internal evaluation of health personnel } \\
\text { made by the organization, alongside } \\
\text { other aspects related to services and } \\
\text { benefits. } \\
\text { - Observation of providers } \\
\text { - Review of IEC materials } \\
\text { - Place gender and equality posters in } \\
\text { examination rooms } \\
\text { - Self training and retraining of personnel } \\
\text { - Update all SRH material }\end{array}$ & $\begin{array}{l}6 \\
3 \\
8 \\
2 \\
7 \\
2\end{array}$ \\
\hline $\begin{array}{l}\text { VI.2 Inclusive language is } \\
\text { used. }\end{array}$ & 6 & $\begin{array}{l}\text { - Internal evaluation of health personnel } \\
\text { made by the organization, alongside } \\
\text { other aspects related to services and } \\
\text { benefits. } \\
\text { - Observation of providers } \\
\text { - Review of IEC materials } \\
\text { - Place gender and equality posters in } \\
\text { examination rooms } \\
\text { - Self training and retraining of personnel } \\
\text { - Update all SRH material }\end{array}$ & $\begin{array}{l}6 \\
3 \\
8 \\
2 \\
7 \\
2\end{array}$ \\
\hline $\begin{array}{l}\text { VII. } 1 \text { There are IEC and } \\
\text { training materials with } \\
\text { information on sexual and } \\
\text { reproductive rights, client } \\
\text { rights and women's rights. }\end{array}$ & 7 & $\begin{array}{l}\text { - Develop a brochure and a poster for this } \\
\text { - Review of IEC materials } \\
\text { - Compile IEC materials that include this } \\
\text { information } \\
\text { - Photocopy IEC materials } \\
\text { - Delivery of material to examination } \\
\text { rooms } \\
\text { - Development of educational material } \\
\text { with sexual and reproductive rights } \\
\text { content } \\
\text { - Manage financial resources to } \\
\text { reproduce SRH material. }\end{array}$ & $\begin{array}{l}1 \\
8 \\
5 \\
2 \\
2 \\
3 \\
2\end{array}$ \\
\hline
\end{tabular}




\begin{tabular}{|c|c|c|c|}
\hline Unmet standards & $\begin{array}{l}\text { Total actions to } \\
\text { improve } \\
\text { standards }\end{array}$ & Solutions suggested & $\begin{array}{c}\text { Number of } \\
\text { units that } \\
\text { suggested } \\
\text { solution }\end{array}$ \\
\hline $\begin{array}{l}\text { VII.2 There are IEC and } \\
\text { training materials with } \\
\text { information on aspects of } \\
\text { sexual and reproductive } \\
\text { health }\end{array}$ & 7 & $\begin{array}{l}\text { - Develop a brochure and a poster for this } \\
\text { - Review of IEC materials } \\
\text { - Compile IEC materials that include this } \\
\text { information } \\
\text { - Photocopy IEC materials } \\
\text { - Delivery of material to examination } \\
\text { rooms } \\
\text { - Prepare of educational material that is } \\
\text { missing such as Pap smears, breast } \\
\text { exams, etc. } \\
\text { - Manage financial resources to } \\
\text { reproduce SRH material. }\end{array}$ & $\begin{array}{l}1 \\
8 \\
5 \\
2 \\
2 \\
3 \\
2\end{array}$ \\
\hline $\begin{array}{l}\text { VII. } 3 \text { There is visual and } \\
\text { accessible information on the } \\
\text { health facility (services } \\
\text { provided, schedules and } \\
\text { price list) }\end{array}$ & 4 & $\begin{array}{l}\text { - Development of list of benefits, costs, } \\
\text { service providers and opening hours. } \\
\text { - Create a flowchart of clients, services } \\
\text { offered, opening hours and tariffs. } \\
\text { - Update fee announcements } \\
\text { - Work on a signposting system within the } \\
\text { facility }\end{array}$ & $\begin{array}{l}7 \\
1 \\
1 \\
1\end{array}$ \\
\hline $\begin{array}{l}\text { VIII. } 1 \text { There is a mechanism } \\
\text { in place to establish } \\
\text { programmatic changes } \\
\text { based on clients' } \\
\text { suggestions }\end{array}$ & 8 & $\begin{array}{l}\text { - Begin to use a suggestion box for users } \\
\text { - Presentation and analysis of results with } \\
\text { - } \text { Dealth personnel. } \\
\text { - } \text { user suggestions } \\
\text { - Set a quality committee in place } \\
\text { - Collection and analysis of client } \\
\text { information } \\
\text { - Keep the Suggestion Box by placing it } \\
\text { somewhere new, promoting its use } \\
\text { more. } \\
\text { - Put together a questionnaire with } \\
\text { detailed questions and simple selections } \\
\text { for suggestions. } \\
\text { - Use quality assurance project's (QAP) } \\
\text { satisfaction surveys. }\end{array}$ & $\begin{array}{l}7 \\
7 \\
6 \\
1 \\
1 \\
1 \\
\\
3 \\
1\end{array}$ \\
\hline $\begin{array}{r}\text { Total actions proposed for } \\
\text { delivery service units }\end{array}$ & 148 & & \\
\hline \multicolumn{4}{|l|}{ Management support units } \\
\hline $\begin{array}{l}\text { I. } 1 \text { There is a declaration in } \\
\text { place that promotes } \\
\text { women's empowerment }\end{array}$ & 6 & $\begin{array}{l}\text { - Review of documents (policies and } \\
\text { norms) } \\
\text { - Write and institutional declaration of } \\
\text { women's empowerment. } \\
\text { - Disseminate the institution's statement. } \\
\text { - Review documentation (Strategic Plan } \\
\text { and Human Resource Manual) } \\
\text { - Adjusting documents } \\
\text { - Document implementation }\end{array}$ & $\begin{array}{l}7 \\
7 \\
7 \\
1 \\
1 \\
1 \\
5\end{array}$ \\
\hline
\end{tabular}




\begin{tabular}{|c|c|c|c|}
\hline Unmet standards & $\begin{array}{l}\text { Total actions to } \\
\text { improve } \\
\text { standards }\end{array}$ & Solutions suggested & $\begin{array}{c}\text { Number of } \\
\text { units that } \\
\text { suggested } \\
\text { solution }\end{array}$ \\
\hline $\begin{array}{l}\text { I.2 There is a declaration in } \\
\text { place that prohibits gender- } \\
\text { based discrimination }\end{array}$ & 5 & $\begin{array}{l}\text { - Internalize concepts within policies } \\
\text { - Write the institutional declaration that } \\
\text { prohibits discrimination of women. } \\
\text { - Disseminate the statement among } \\
\text { employees } \\
\text { - Awareness-raising workshops on } \\
\text { gendered terminology } \\
\text { - Adjustment of personnel recruitment, } \\
\text { selection and promotion policies. }\end{array}$ & $\begin{array}{l}1 \\
7 \\
7 \\
2 \\
1\end{array}$ \\
\hline $\begin{array}{l}\text { I.4 There is a declaration in } \\
\text { place that prohibits the } \\
\text { abuse of power in the } \\
\text { institution }\end{array}$ & 3 & $\begin{array}{l}\text { - Internalize concepts within policies } \\
\text { - Write an institutional declaration that } \\
\text { prohibits the abuse of power in the } \\
\text { institution } \\
\text { - Make the declaration known in the } \\
\text { institution }\end{array}$ & $\begin{array}{l}1 \\
7 \\
7\end{array}$ \\
\hline $\begin{array}{l}\text { I.5 At least } 80 \text { percent of } \\
\text { personnel feel that the } \\
\text { institution's direction or } \\
\text { management is receptive to } \\
\text { their opinions and } \\
\text { suggestions }\end{array}$ & 7 & $\begin{array}{l}\text { - Opinion survey (to know the personnel's } \\
\text { degree of motivation) by means of } \\
\text { surveys and/or interviews } \\
\text { - Improve an efficient internal } \\
\text { communication system for information, } \\
\text { questions and complaints. } \\
\text { - Carry out a diagnosis of personnel by } \\
\text { - } \text { - Adjustment of the operations and } \\
\text { - Rtrategic coordination system } \\
\text { - Results of the performance evaluation } \\
\text { - Meendom samples of personnel } \\
\text { suggestions in general assemblies and } \\
\text { team meetings }\end{array}$ & $\begin{array}{l}6 \\
4 \\
2 \\
1 \\
6 \\
1 \\
1\end{array}$ \\
\hline $\begin{array}{l}\text { I.6 At least } 80 \text { percent of } \\
\text { personnel feel their } \\
\text { recommendations or } \\
\text { suggestions are put into } \\
\text { practice }\end{array}$ & 8 & $\begin{array}{l}\text { - Opinion survey (to know the personnel's } \\
\text { degree of motivation) by means of } \\
\text { surveys and/or interviews } \\
\text { - Strategic planning document } \\
\text { - Diagnosis of personnel by means of an } \\
\text { anonymous questionnaire } \\
\text { - Adjustment of coordination system } \\
\text { - Share the minutes from the meeting at } \\
\text { the technical committee meetings in } \\
\text { order to take decisions and actions } \\
\text { - By means of the Technical } \\
\text { Committees, make Regional Level } \\
\text { decisions known to Consultative } \\
\text { Committees } \\
\text { - Follow up on compliance with these } \\
\text { decisions and actions } \\
\text { - Internal personnel satisfaction surveys }\end{array}$ & $\begin{array}{l}6 \\
1 \\
2 \\
1 \\
1\end{array}$ \\
\hline
\end{tabular}




\begin{tabular}{|c|c|c|c|}
\hline Unmet standards & $\begin{array}{l}\text { Total actions to } \\
\text { improve } \\
\text { standards }\end{array}$ & Solutions suggested & $\begin{array}{c}\text { Number of } \\
\text { units that } \\
\text { suggested } \\
\text { solution }\end{array}$ \\
\hline $\begin{array}{l}\text { I.7 At least } 80 \text { percent of } \\
\text { personnel feel motivated to } \\
\text { give opinions and make } \\
\text { suggestions }\end{array}$ & 8 & $\begin{array}{l}\text { - Meetings with personnel for } \\
\text { implementing focus groups } \\
\text { - Diagnosis of personnel by means of an } \\
\text { anonymous questionnaire } \\
\text { - Performance evaluation } \\
\text { - Adjustment of operations and strategic } \\
\text { coordination system } \\
\text { - Strengthen the development of general } \\
\text { meetings to make progress and } \\
\text { difficulties known } \\
\text { - Publicly recognize personnel work and } \\
\text { effort by means of thank-you memos } \\
\text { and congratulatory memos, etc. } \\
\text { - When writing up proposals, consider } \\
\text { resources in the budgets for internal } \\
\text { training and incentives to personnel: } \\
\text { fieldwork equipment } \\
\text { - Personnel perceptions surveys and } \\
\text { feedback }\end{array}$ & $\begin{array}{l}1 \\
2 \\
7 \\
1 \\
5\end{array}$ \\
\hline $\begin{array}{l}\text { I.8 At least } 80 \text { percent of } \\
\text { personnel feel the institution } \\
\text { has a collective and } \\
\text { teamwork environment }\end{array}$ & 6 & $\begin{array}{l}\text { - Opinion survey by means of surveys or } \\
\text { other instruments to gather information. } \\
\text { - Meetings for strengthening of personnel } \\
\text { - Diagnosis of personnel by means of an } \\
\text { anonymous questionnaire } \\
\text { - Adjustment of operations and strategic } \\
\text { coordination system } \\
\text { - Awareness raising workshop } \\
\text { - Ensure that in all planning and } \\
\text { coordination meetings there are } \\
\text { moments of consultation, dialogue } \\
\text { and/or suggestions }\end{array}$ & $\begin{array}{l}7 \\
5 \\
2 \\
1 \\
2 \\
2\end{array}$ \\
\hline $\begin{array}{l}\text { I.9 At least } 80 \text { percent of } \\
\text { personnel feel that the } \\
\text { institution is receptive to } \\
\text { explanations when they } \\
\text { have to leave work for family } \\
\text { reasons }\end{array}$ & 5 & $\begin{array}{l}\text { - Opinion poll surveys } \\
\text { - Making guidelines known through HR. } \\
\text { - Diagnosis of personnel by means of } \\
\text { anonymous questionnaire } \\
\text { - Adjust the operations and strategic } \\
\text { coordination system } \\
\text { - Awareness-raising workshop }\end{array}$ & $\begin{array}{l}7 \\
2 \\
2 \\
1 \\
2\end{array}$ \\
\hline $\begin{array}{l}\text { I. } 10 \text { Less than } 20 \text { percent of } \\
\text { personnel feel that one sex } \\
\text { in particular receives } \\
\text { preferential treatment at their } \\
\text { institution }\end{array}$ & 4 & $\begin{array}{l}\text { - Opinion poll by means of surveys or } \\
\text { other instruments to gather information } \\
\text { - Diagnosis of personnel by means of } \\
\text { anonymous questionnaire } \\
\text { - Adjust the operations and strategic } \\
\text { coordination system } \\
\text { - Awareness-raising workshop }\end{array}$ & $\begin{array}{l}7 \\
2 \\
1 \\
2\end{array}$ \\
\hline
\end{tabular}




\begin{tabular}{|c|c|c|c|}
\hline Unmet standards & $\begin{array}{l}\text { Total actions to } \\
\text { improve } \\
\text { standards }\end{array}$ & Solutions suggested & $\begin{array}{c}\text { Number of } \\
\text { units that } \\
\text { suggested } \\
\text { solution }\end{array}$ \\
\hline $\begin{array}{l}\text { III.1 At least } 80 \text { percent of } \\
\text { personnel know the definition } \\
\text { of sexual and reproductive } \\
\text { health }\end{array}$ & 8 & $\begin{array}{l}\text { - Training workshop on health and } \\
\text { - gender } \\
\text { - Dissemination of information (thematic) } \\
\text { - SRH training workshop } \\
\text { - Personnel training and retraining } \\
\text { - Monitoring and supervision. } \\
\text { - Include messages in materials for } \\
\text { distribution to clients } \\
\text { - Take advantage of meetings and } \\
\text { workshops with personnel to raise } \\
\text { awareness of project and introduce the } \\
\text { concepts } \\
\text { - Plan and apply SRH self-training } \\
\text { modules (two for health personnel and } \\
\text { one for all personnel) }\end{array}$ & $\begin{array}{l}7 \\
7 \\
5 \\
4 \\
7 \\
1 \\
1 \\
1 \\
1\end{array}$ \\
\hline $\begin{array}{l}\text { III.3 At least } 80 \text { percent of } \\
\text { personnel know the definition } \\
\text { of gender }\end{array}$ & 6 & $\begin{array}{l}\text { - Gender awareness-raising and training } \\
\text { - Training and retraining of personnel } \\
\text { - Monitoring and supervision } \\
\text { - Include messages in materials for } \\
\text { distribution among clients. } \\
\text { - Take advantage of meetings and } \\
\text { workshops with personnel to raise } \\
\text { awareness of project and introduce } \\
\text { concepts } \\
\text { - Plan and apply self-training modules on } \\
\text { SRH and gender (two for health } \\
\text { personnel and one for all personnel) }\end{array}$ & $\begin{array}{l}7 \\
7 \\
7 \\
1 \\
1 \\
1 \\
1\end{array}$ \\
\hline $\begin{array}{l}\text { V.2 Conditions of cleanliness } \\
\text { and comfort are satisfactory }\end{array}$ & 8 & $\begin{array}{l}\text { - Permanent follow-up of cleaning staff } \\
\text { - Monitoring and supervision } \\
\text { - Development of observation guide } \\
\text { - Application guide } \\
\text { - Equipment } \\
\text { - The institution has personnel that } \\
\text { carries out this job } \\
\text { - Define weekly inspector teams per } \\
\text { project }\end{array}$ & $\begin{array}{l}2 \\
4 \\
1 \\
1 \\
1 \\
1 \\
1 \\
2\end{array}$ \\
\hline $\begin{array}{l}\text { VI. } 1 \text { Non-discriminatory } \\
\text { language is used }\end{array}$ & 6 & $\begin{array}{l}\text { - Documented observation: checklist } \\
\text { - Raising awareness of personnel } \\
\text { - Self-assessment (PROCOSI survey) } \\
\text { - Review of IEC materials } \\
\text { - Adjustment of current documents } \\
\text { - Distribution of conceptualization for } \\
\text { raising awareness of topic }\end{array}$ & $\begin{array}{l}1 \\
7 \\
1 \\
7 \\
6\end{array}$ \\
\hline
\end{tabular}




\begin{tabular}{|c|c|c|c|}
\hline Unmet standards & $\begin{array}{l}\text { Total actions to } \\
\text { improve } \\
\text { standards }\end{array}$ & Solutions suggested & $\begin{array}{c}\text { Number of } \\
\text { units that } \\
\text { suggested } \\
\text { solution }\end{array}$ \\
\hline $\begin{array}{l}\text { VI.2 Inclusive language is } \\
\text { used }\end{array}$ & 7 & $\begin{array}{l}\text { - Documented observation: checklist } \\
\text { - Raising awareness of personnel } \\
\text { - Self-assessment (PROCOSI survey) } \\
\text { - Monitoring and supervision } \\
\text { - Review of IEC materials } \\
\text { - Adjustment of current documents } \\
\text { - Distribution of conceptualization for } \\
\text { raising awareness of topic }\end{array}$ & $\begin{array}{l}1 \\
7 \\
1 \\
1 \\
7 \\
6 \\
7\end{array}$ \\
\hline $\begin{array}{l}\text { VII.1 There are IEC and } \\
\text { training materials with } \\
\text { information on sexual and } \\
\text { reproductive rights, client } \\
\text { rights and women's rights }\end{array}$ & 4 & $\begin{array}{l}\text { - Checklist } \\
\text { - Review of policies } \\
\text { - Socialization of materials } \\
\text { - Adjustments of norms and policies in } \\
\text { relation to IEC materials }\end{array}$ & $\begin{array}{l}4 \\
1 \\
7 \\
7\end{array}$ \\
\hline $\begin{array}{l}\text { There are IEC and training } \\
\text { materials with information on } \\
\text { aspects of sexual and } \\
\text { reproductive health }\end{array}$ & 4 & $\begin{array}{l}\text { - Checklist } \\
\text { - Review of policies } \\
\text { - Socialization of materials } \\
\text { - Adjustments of norms and policies in } \\
\text { relation to IEC materials }\end{array}$ & $\begin{array}{l}4 \\
1 \\
7 \\
7\end{array}$ \\
\hline $\begin{array}{r}\text { Total actions proposed } \\
\text { management support units }\end{array}$ & 95 & & \\
\hline
\end{tabular}




\section{Annex 4: $\quad$ Changes in unmet standards, pre- and post-intervention}

\begin{tabular}{|c|c|c|}
\hline \multirow{2}{*}{ Most frequently unmet standards } & \multicolumn{2}{|c|}{ Number of units } \\
\hline & Pre & Post \\
\hline Units with services & $\max =7$ & $\max =7$ \\
\hline I. 1 There is a declaration that promotes women's empowerment & 0 & 6 \\
\hline $\begin{array}{l}\text { I.11 At least } 50 \% \text { of sexual and reproductive health consultations are provided } \\
\text { to couples }\end{array}$ & 0 & 0 \\
\hline II.2 At least $80 \%$ of providers wear visible nametags & 0 & 6 \\
\hline $\begin{array}{l}\text { II.5 At least } 80 \% \text { of providers explore aspects related to the client's sexual and } \\
\text { reproductive health during consultations/counseling visits }\end{array}$ & 0 & 5 \\
\hline $\begin{array}{l}\text { II.7 At least } 80 \text { percent of providers use didactic material (drawings, brochures, } \\
\text { flipcharts or other material) to reinforce their explanations during } \\
\text { consultations/counseling visits }\end{array}$ & 0 & 5 \\
\hline $\begin{array}{l}\text { II.9 At least } 80 \text { percent of providers explain to the client details of their } \\
\text { diagnosis in consultations/counseling sessions }\end{array}$ & 0 & 7 \\
\hline $\begin{array}{l}\text { II. } 14 \text { At least } 80 \text { percent of providers explain what it is they after physical or } \\
\text { pelvic examinations }\end{array}$ & 0 & 7 \\
\hline $\begin{array}{l}\text { II.15 At least } 80 \text { percent of providers provide reinforcement educational } \\
\text { materials to the client }\end{array}$ & 0 & 4 \\
\hline $\begin{array}{l}\text { II.16 Less than } 20 \text { percent of providers say there a delay of more than half an } \\
\text { hour between the time health personnel reach the establishment and the } \\
\text { moment in which they begin to attend clients }\end{array}$ & 0 & 7 \\
\hline $\begin{array}{l}\text { II. } 17 \text { Less than } 20 \text { percent of clients say they have waited over half an hour to } \\
\text { be seen }\end{array}$ & 0 & 5 \\
\hline $\begin{array}{l}\text { II.19 At least } 80 \text { percent of providers dedicate their time to the client without } \\
\text { interruptions during the consultations /counseling services }\end{array}$ & 0 & 7 \\
\hline $\begin{array}{l}\text { II.20 At least } 80 \text { percent of personnel know and promote the use of dual } \\
\text { protection methods }\end{array}$ & 0 & 6 \\
\hline II.21 At least 80 percent of personnel know and promote the Pap test & 0 & 6 \\
\hline $\begin{array}{l}\text { II.22 At least } 80 \text { percent of personnel know and promote breast self- } \\
\text { examination }\end{array}$ & 0 & 6 \\
\hline $\begin{array}{l}\text { II.24 At least } 80 \text { percent of personnel set times according to client's customs } \\
\text { and knowledge }\end{array}$ & 0 & 7 \\
\hline $\begin{array}{l}\text { II.25 At least } 80 \text { percent of personnel keep doors and windows shut to avoid air } \\
\text { currents during consultation }\end{array}$ & 0 & 7 \\
\hline II.26 At least 80 percent of personnel respects clients' symbolic practices & 0 & 7 \\
\hline III.3 At least 80 percent of personnel know the definition of gender & 0 & 7 \\
\hline V.2 Conditions of cleanliness and comfort are satisfactory & 0 & 7 \\
\hline V.3 Equipment is available and in good condition & 0 & 7 \\
\hline V.4 There are conditions to ensure client confidentiality and privacy & 0 & 7 \\
\hline $\begin{array}{l}\text { V.7 At least } 80 \text { percent of clients feel comfortable enough to ask questions and } \\
\text { clear up doubts with providers }\end{array}$ & 0 & 7 \\
\hline $\begin{array}{l}\text { V.8 At least } 80 \text { percent of clients consider that the time spent during } \\
\text { consultation is enough }\end{array}$ & 0 & 6 \\
\hline
\end{tabular}




\begin{tabular}{|c|c|c|}
\hline V.10 At least 80 percent of clients are attended by a person of the preferred sex & 0 & 7 \\
\hline $\begin{array}{l}\text { V.11 At least } 80 \text { percent of clients consider that office hours adapt to their } \\
\text { (gender related) needs }\end{array}$ & 0 & 7 \\
\hline VI.1 Non-discriminatory language is used & 0 & 7 \\
\hline VI.2 Inclusive language is used & 0 & 7 \\
\hline $\begin{array}{l}\text { VII.1 There are IEC and training materials with information on sexual and } \\
\text { reproductive rights, client rights, women's rights }\end{array}$ & 0 & 7 \\
\hline $\begin{array}{l}\text { VII.2 There are IEC and training materials with information on aspects of sexual } \\
\text { and reproductive health }\end{array}$ & 0 & 7 \\
\hline $\begin{array}{l}\text { VII. } 3 \text { There is visual and accessible information on the health facility (services } \\
\text { provided, schedules and price list) }\end{array}$ & 0 & 7 \\
\hline $\begin{array}{l}\text { VIII.1 There is a mechanism in place to establish programmatic changes based } \\
\text { on client suggestions }\end{array}$ & 0 & 7 \\
\hline Management support units & $\max =7$ & $\max =7$ \\
\hline I.1 There is a declaration that promotes women's empowerment & 0 & 7 \\
\hline I.2 There is a declaration that prohibits gender-based discrimination & 0 & 7 \\
\hline I.4 There is a declaration that forbids power abuse in the institution & 0 & 6 \\
\hline $\begin{array}{l}\text { I.5 At least } 80 \text { percent of personnel feel that the institution's direction or } \\
\text { management is receptive to their opinions and suggestions }\end{array}$ & 0 & 7 \\
\hline $\begin{array}{l}\text { I. } 6 \text { At least } 80 \text { percent of personnel feel that their recommendations or } \\
\text { suggestions are put into practice }\end{array}$ & 0 & 7 \\
\hline $\begin{array}{l}1.7 \text { At least } 80 \text { percent of personnel feel motivated to express opinions and } \\
\text { make suggestions }\end{array}$ & 0 & 7 \\
\hline $\begin{array}{l}\text { I.8 At least } 80 \text { percent of personnel feel that the institution has a collective and } \\
\text { team work environment }\end{array}$ & 0 & 7 \\
\hline $\begin{array}{l}\text { I.9 At least } 80 \text { percent of personnel feel that the institution is receptive to } \\
\text { explanations for leaving work when required by family reasons }\end{array}$ & 0 & 7 \\
\hline $\begin{array}{l}\text { I.10 Less than } 20 \text { percent of personnel feel that in their institution preferential } \\
\text { treatment is given to one sex in particular }\end{array}$ & 0 & 7 \\
\hline $\begin{array}{l}\text { III. } 1 \text { At least } 80 \text { percent of personnel know the definition of sexual and } \\
\text { reproductive health }\end{array}$ & 0 & 7 \\
\hline III.3 At least 80 percent of personnel know the definition of gender & 0 & 7 \\
\hline V.2 Conditions of cleanliness and comfort are satisfactory & 0 & 7 \\
\hline VI.1 Non-discriminatory language is used & 0 & 7 \\
\hline VI.2 Inclusive language is used & 0 & 7 \\
\hline $\begin{array}{l}\text { VII. } 1 \text { There are IEC and training materials with information on sexual and } \\
\text { reproductive rights, client rights, women's rights }\end{array}$ & 0 & 7 \\
\hline $\begin{array}{l}\text { VII.2 There are IEC and training materials with information on aspects of sexual } \\
\text { and reproductive health }\end{array}$ & 0 & 7 \\
\hline
\end{tabular}


Annex 5: Costs by unit and type of expenditure (in \$US)

\begin{tabular}{|c|c|c|c|c|c|c|}
\hline Unit & $\begin{array}{c}\text { Changes in } \\
\text { policies and } \\
\text { practices }\end{array}$ & $\begin{array}{l}\text { Meetings } \\
\text { and } \\
\text { workshops }\end{array}$ & $\begin{array}{l}\text { Improvement in } \\
\text { infrastructure, } \\
\text { equipment and } \\
\text { furniture }\end{array}$ & $\begin{array}{c}\text { Development } \\
\text { and distribution } \\
\text { of IEC material }\end{array}$ & Supervision & $\begin{array}{l}\text { Total } \\
\text { per } \\
\text { unit }\end{array}$ \\
\hline \multicolumn{7}{|c|}{ Service delivery units } \\
\hline 1 & 408.35 & $3,544.26$ & 0.00 & $1,948.75$ & 183.42 & 6,085 \\
\hline 2 & 154.61 & 808.23 & 0.00 & 38.40 & 3.37 & 1,005 \\
\hline 3 & 52.49 & $1,088.65$ & $5,062.22$ & 0.00 & 25.06 & 6,228 \\
\hline 4 & 34.54 & $1,221.82$ & 0.00 & 0.00 & 0.00 & 1,256 \\
\hline 5 & 2.99 & 307.73 & 0.00 & 0.00 & 4.61 & 316 \\
\hline 6 & 484.41 & $6,841.27$ & $5,153.24$ & 14.34 & 41.65 & 12,535 \\
\hline 7 & 0.00 & 440.77 & 162.47 & 0.00 & 0.00 & 603 \\
\hline 8 & N/D & N/D & N/D & N/D & N/D & N/D \\
\hline Totals & 1.137 & 14,253 & 10,377 & 2,001 & 258 & 28,027 \\
\hline \multicolumn{7}{|c|}{ Management support units } \\
\hline 1 & 696.38 & 629.05 & 0.00 & $1,303.49$ & 0.00 & 2,629 \\
\hline 2 & 886.03 & 329.68 & 0.00 & 78.55 & 63.47 & 1,358 \\
\hline 3 & 95.14 & 832.42 & 0.00 & 87.03 & 6.73 & 1,021 \\
\hline 4 & 462.59 & 995.51 & 0.00 & 0.00 & 5.49 & 1,464 \\
\hline 5 & $1,368.95$ & $1,651.87$ & 0.00 & 707.23 & 53.99 & 3,782 \\
\hline 6 & 115.21 & $3,106.23$ & 0.00 & 0.00 & 24.31 & 3,246 \\
\hline 7 & $2,073.94$ & 665.71 & 0.00 & 160.22 & 37.78 & 2,938 \\
\hline Totals & 5.698 & 8.211 & 0 & 2.336 & 191 & 16,438 \\
\hline
\end{tabular}




\section{Annex 6: Costs per unit and other distribution of type of expenses}

\begin{tabular}{|c|c|c|c|c|c|c|c|c|c|}
\hline \multirow{3}{*}{ Unit } & \multicolumn{8}{|c|}{ Type of cost } & \multirow{3}{*}{ Totals } \\
\hline & \multicolumn{2}{|c|}{ Personnel time } & \multicolumn{2}{|c|}{$\begin{array}{c}\text { Recurrent } \\
\text { expenses }\end{array}$} & \multicolumn{2}{|c|}{$\begin{array}{l}\text { Infrastructure. } \\
\text { equipment and } \\
\text { furniture }\end{array}$} & \multicolumn{2}{|c|}{ IEC materials } & \\
\hline & US\$ & $\%$ & US\$ & $\%$ & US\$ & $\%$ & US\$ & $\%$ & \\
\hline \multicolumn{10}{|c|}{ Service delivery units } \\
\hline 1 & $4,309.48$ & $71 \%$ & 528.55 & $9 \%$ & 0.00 & $0 \%$ & $1,246.88$ & $20 \%$ & 6,085 \\
\hline 2 & 824.31 & $82 \%$ & 155.49 & $15 \%$ & 0.00 & $0 \%$ & 24.94 & $2 \%$ & 1,005 \\
\hline 3 & 721.57 & $12 \%$ & 469.08 & $8 \%$ & $5,037.91$ & $81 \%$ & 0.00 & $0 \%$ & 6,229 \\
\hline 4 & $1,133.04$ & $90 \%$ & 123.32 & $10 \%$ & 0.00 & $0 \%$ & 0.00 & $0 \%$ & 1,256 \\
\hline 5 & 177.06 & $56 \%$ & 138.53 & $44 \%$ & 0.00 & $0 \%$ & 0.00 & $0 \%$ & 316 \\
\hline 6 & $6,222.57$ & $50 \%$ & $4,253.99$ & $34 \%$ & $2,058.23$ & $16 \%$ & 0.00 & $0 \%$ & 12,535 \\
\hline 7 & 366.46 & $61 \%$ & 145.14 & $24 \%$ & 91.65 & $15 \%$ & 0.00 & $0 \%$ & 603 \\
\hline 8 & N/D & N/D & N/D & N/D & N/D & N/D & N/D & $\mathrm{N} / \mathrm{D}$ & N/D \\
\hline Totals & 13,754 & $49 \%$ & 5,814 & $21 \%$ & 7,188 & $26 \%$ & 1,272 & $5 \%$ & 28,029 \\
\hline \multicolumn{10}{|c|}{ Management support units } \\
\hline 1 & $2,305.61$ & $88 \%$ & 24.19 & $1 \%$ & 0.00 & $0 \%$ & 299.25 & $11 \%$ & 2,629 \\
\hline 2 & $1,097.88$ & $81 \%$ & 230.05 & $17 \%$ & 0.00 & $0 \%$ & 29.93 & $2 \%$ & 1,358 \\
\hline 3 & 967.71 & $95 \%$ & 53.74 & $5 \%$ & 0.00 & $0 \%$ & 0.00 & $0 \%$ & 1,021 \\
\hline 4 & $1,339.90$ & $92 \%$ & 123.69 & $8 \%$ & 0.00 & $0 \%$ & 0.00 & $0 \%$ & 1,464 \\
\hline 5 & $3,495.39$ & $92 \%$ & 286.66 & $8 \%$ & 0.00 & $0 \%$ & 0.00 & $0 \%$ & 3,782 \\
\hline 6 & $3,117.58$ & $96 \%$ & 128.18 & $4 \%$ & 0.00 & $0 \%$ & 0.00 & $0 \%$ & 3,246 \\
\hline 7 & $2,763.47$ & $94 \%$ & 112.59 & $4 \%$ & 0.00 & $0 \%$ & 61.47 & $2 \%$ & 2,937 \\
\hline Totals & 15,088 & $92 \%$ & 960 & $6 \%$ & $\mathbf{0}$ & 0\% & 390 & $2 \%$ & 16,438 \\
\hline
\end{tabular}

